\title{
The Stereochemistry of the Nozaki-Hiyama-Kishi Reaction and the Construction of 10- Membered Lactones. The Enantioselective Total Synthesis of (-)-Decarestrictine D.
}

\author{
Ronaldo A. Pilli* and Mauricio M. Victor
}

Instituto de Química, Universidade Estadual de Campinas, CP 6154, 13083-970 Campinas - SP, Brazil

\begin{abstract}
O uso da reação de Nozaki-Hiyama-Kishi para a formação de lactonas de 10 membros é descrita. A influência dos grupos de proteção em C4 e C5 sobre a estereoquímica do novo centro estereogênico formado em C7 foi investigada. A utilidade desta metodologia ficou demonstrada com a síntese total e estereosseletiva da (-)-decarestrictina D a partir do 1,3-propanodiol e poliidroxibutirato $(\mathrm{PHB})$ em 13 etapas e 6,3\% de rendimento total.
\end{abstract}

The use of the intramolecular Nozaki-Hiyama-Kishi reaction to construct 10-membered lactones is described. The influence of the nature of the protecting groups at $\mathrm{C} 4$ and $\mathrm{C} 5$ on the stereochemistry of the newly formed stereogenic center at C7 was investigated. The utility of this methodology has been demonstrated in the stereoselective total synthesis of (-)-decarestrictine D from 1,3-propanediol and polyhydroxybutyrate (PHB) in 13 steps and 6.3\% overall yield.

Keywords: decarestrictine D, decanolide, Nozaki-Hiyama-Kishi reaction, lactone

\section{Introduction}

Decarestrictine D (1) is a 10-membered lactone isolated from Penicillium corylophilum, simplicissimum ${ }^{\text {1a-c }}$ and independently from the Canadian Tuckahoe fungi Polyporus tuberaster ${ }^{\mathrm{ld}}$ and named as tuckolide. A general panel of whole cell screening demonstrated that decarestrictine D inhibits cholesterol biosynthesis in HEPG2 liver cells and this beneficial effect was corroborated by in vivo studies with normolipidemic rats. In addition, it appears that decarestrictine D is highly selective in that it exhibits no significant antibacterial, antifungal, antiprotozoal, or antiviral activity. However, recent studies ${ }^{2}$ revealed DNA-binding activity for decarestrictine D and the corresponding bisglycosylated derivatives, disclosing new avenues of opportunities in structure-activity relationship. Such significant biological properties exhibited by decarestrictine D contributed much to the interest in devising synthetic approaches to this family of natural products.

While the relative stereochemistry was provided by $\mathrm{X}$ ray analysis ${ }^{1 b}$, its absolute configuration has been recently established by total synthesis ${ }^{3}$ and $\mathrm{X}$-ray analysis of a chiral

* e-mail: pilli@iqm.unicamp.br

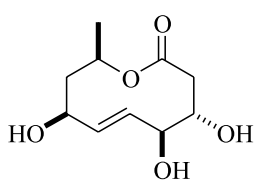

Decarestrictine D (1)

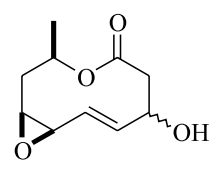

Decarestrictine A (2)

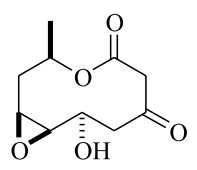

Decarestrictine B (3)

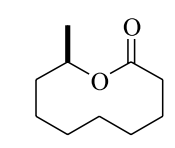

Phoracantholide I (4)

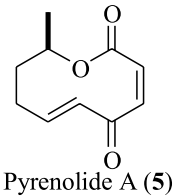

derivative $^{2}$. Other members of the 10-membered lactone family ${ }^{4}$ include decarestrictines A (2) and B (3), phoracantholide I (4) ${ }^{5}$ and pyrenolide A (5) ${ }^{6}$.

The synthetic approach to lactones has traditionally focused mainly on the use of fragmentation/ring expansion reactions and on lactonization strategies in order to build the lactone ring ${ }^{7}$. Recently, examples of the construction of lactones through the formation of C-C bond appeared ${ }^{8}$ and the intramolecular Nozaki-Hiyama-Kishi (NHK) coupling reaction ${ }^{9}$ stands as a promising protocol ${ }^{10}$. Moreover, the factors controlling the stereochemical outcome of the $\mathrm{C}-\mathrm{C}$ bond forming step are unknown which prompted us to investigate how the conformational bias in the acyclic precursor influences the stereochemical course of the reaction. 
According to our synthetic plan, the construction of the decanolide ring would arise from the formation of the C6-C7 bond. The stereogenic centers at $\mathrm{C} 3$ and $\mathrm{C} 4$ could conceivably come from the chiral pool by de novo contruction through asymmetric methodology such as Sharpless asymmetric dihydroxylation (Scheme 1). The C7-C10 fragment 8 was planned to be prepared from natural biopolymer polyhydroxybutyrate ${ }^{11}(\mathrm{PHB}, 11)$ while the $\mathrm{C} 1$ C6 fragment 7 could be obtained either from tartaric acid 9 (path A) or through Sharpless asymmetric dihydroxylation $^{12}$ (path B). The choice of fragment 7 poses the additional opportunity to investigate the influence of the protecting groups at $\mathrm{C} 3$ and $\mathrm{C} 4$ (cyclic or acyclic) on the stereochemical outcome of the Nozaki-Hiyama-Kishi cyclization. The different local conformations that might be enforced by the protecting groups at $\mathrm{C} 3$ and $\mathrm{C} 4$ were expected to impart changes on the geometry of the transition state as proposed by Kishi ${ }^{13}$ and Schreiber ${ }^{14}$.

\section{Results and Discussion}

\section{The C1-C6 fragment 7}

Our first choice for the preparation of optically pure 7 was to employ $(2 R, 3 R)$-diethyl tartrate protected as the corresponding isopropylideneacetal (Scheme 2). After treating $(2 R, 3 R)$-diethyl tartrate 9 with 2,2-dimethoxypropane (DMP) in acetone as solvent, a mixture of dimethyl,<smiles>CC(O)CC(=O)OC(C)CC(O)C=CC(O)C(O)O</smiles>

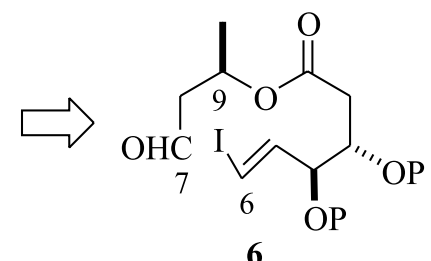<smiles>O=C(O)C[C@@H]([OH2+])[C@@H](O)/C=C/I</smiles><smiles>C1=CCC1</smiles>

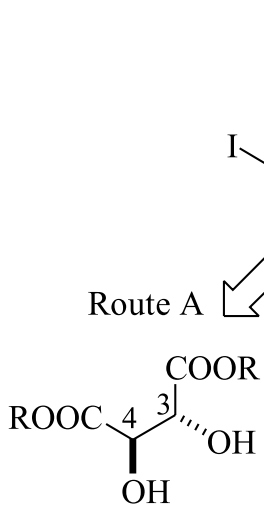

9

7<smiles>[B]=C1CCC2CCC12</smiles><smiles>CCCCOCCC(C)O</smiles>

Route B<smiles>CCOC(=O)/C=C/CCO</smiles>

10<smiles>CC(O)CC(=O)CC(C)(O)O</smiles>

11

Scheme 1. Synthetic plan for the total synthesis of (-)-decarestrictine D (1).

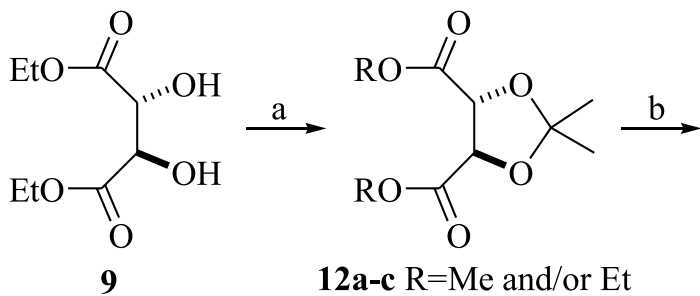<smiles>CC1(C)OC(CO)C(CO)O1</smiles><smiles>CC1(C)OC(CO)C(COS(=O)(=O)c2ccccc2)O1</smiles>

a) acetone:DMP 1:1, PTSA (87\%); b) $\mathrm{NaBH}_{4}$, EtOH, $0{ }^{\circ} \mathrm{C}(60 \%)$; c) NaH, THF, $0{ }^{\circ} \mathrm{C}$ then $\mathrm{TBSCl}(90 \%)$.

Scheme 2. Preparation of threitol 14 from $(2 R, 3 R)$ diethyl tartrate (9). 
diethyl and methylethyl esters 12a-c, as determined by GC and NMR analyses, was formed which was reduced with $\mathrm{NaBH}_{4}$ in ethanol to afford threitol 13 in $60 \%$ overall yield. Monoprotection of diol $\mathbf{1 3}$ was accomplished under the conditions described by McDougal and $\mathrm{Oh}^{15}$ and uneventfully afforded primary alcohol 14 in $90 \%$ yield.

Concomitantly, the preparation of fragment 7 along path B (Scheme 1) was investigated. Monosilylation of 1,3propanediol 15 with TBSClled to 16 in 91\% yield. Swern oxidation afforded aldehyde $\mathbf{1 7}$ which was employed in the next step without further purification (Scheme 3). Horner-Emmons-Wadsworth reaction with the lithium anion of ketophosphonate $\mathbf{1 8}$ afforded $\alpha, \beta$-insaturated esters $\mathbf{1 0 E}$ and $\mathbf{1 0 Z}$ (22:1 ratio). Flash chromatography on silica gel allowed separation of the geometric isomers which were isolated in $70 \%$ (major isomer $\mathbf{1 0 E}$ ) and $3 \%$ (minor isomer 10Z). Dihydroxylation of $\mathbf{1 0 E}$ with AD-mix ${ }^{\circledR}$ $\alpha$ led to $(2 R, 3 S)-19$ in $94 \%$ yield and $91 \%$ enantiomeric excess after analysis by GC on chiral stationary phase ${ }^{16}$. Diol (-)-19 was fully protected as the corresponding TBSether (-)-20 in quantitative yield with TBSCl, imidazole and DMF as solvent.
At this stage we faced the preparation of the corresponding vinylic iodides from alcohol 14 and/or ester 20 and the Takai protocol was elected as our first choice ${ }^{17}$. This method employs the addition of organochromium species to an aldehyde and for that purpose alcohol 14 was oxidized to aldehyde 21 under Swern conditions (Scheme 4). When aldehyde 21 was treated with iodoform (2.0 equiv.) and $\mathrm{CrCl}_{2}$ (6.0 equiv.) at $0{ }^{\circ} \mathrm{C}$ iodide 22 was isolated in low yield (23\%, 2 steps) as a 3:1 mixture of the $E$ and $Z$ isomers, as determined by ${ }^{1} \mathrm{H} \mathrm{NMR}$ analyses ${ }^{18}$, while no reaction was observed when a mixture of 1,4-dioxane-THF $(6: 1)$ was employed ${ }^{19}$.

In another attempt, ester (-)-20 was reduced with DIBAL-H to aldehyde 23 (Scheme 5$)^{20}$ which was treated under the conditions mentioned above for aldehyde $\mathbf{2 1}$ but even after a large reaction time, iodide $\mathbf{2 4}$ was obtained in low yield ( $12 \%$ overall and $24 \%$ yield based on recovered aldehyde) but fortunately a single stereoisomer was formed $^{21}$. In summary, due to the low selectivity observed in the olefination of aldehyde $\mathbf{2 1}$ and the need of homologation imposed by route A we decided to concentrate our efforts on route $\mathrm{B}$.

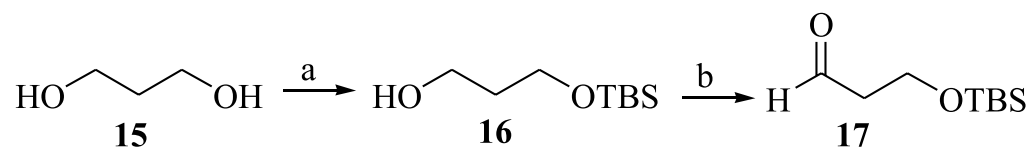<smiles>CCOC(=O)C=CCCO[SbH2]CC</smiles><smiles>CCOC(=O)C(O)C(O)CCO[Sb]</smiles>

(-)-19

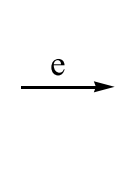

EtO<smiles>CCOC(=O)C([18OH])C(CCO[SbH3])O[SbH3]</smiles>

$(-)-20$

a) NaH, THF, $0{ }^{\circ} \mathrm{C}$ then $\mathrm{TBSCl}(91 \%)$; b) DMSO, $(\mathrm{COCl})_{2}, \mathrm{CH}_{2} \mathrm{Cl}_{2}, \mathrm{Et}_{3} \mathrm{~N},-78{ }^{\circ} \mathrm{C}$; c) NaH, THF, $0{ }^{\circ} \mathrm{C}$ then $\mathbf{1 7}$, rt, $3 \mathrm{~h}$ (73\%, 2 steps, $\left.10 \mathrm{E} / \mathbf{Z} 22: 1\right)$; d) ADmix $\alpha, \mathrm{CH}_{3} \mathrm{SO}_{2} \mathrm{NH}_{2}, \mathrm{tBuOH}: \mathrm{H}_{2} \mathrm{O}(1: 1), 0{ }^{\circ} \mathrm{C}, 24 \mathrm{~h}(94 \%, 91 \%$ ee); e) TBSCl, imidazole, DMF (quant.).

Scheme 3. Preparation of ester (-)-20 from 1,3-propanediol (15).

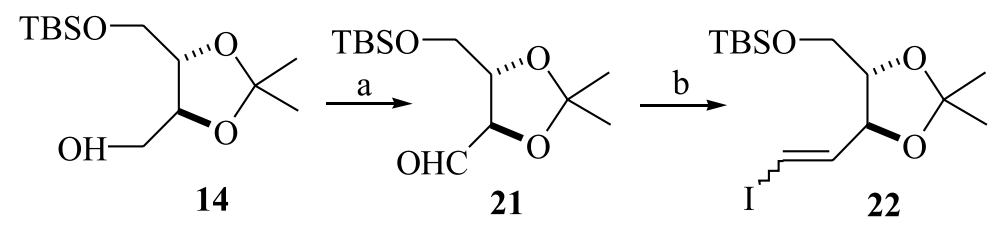

a) DMSO, $(\mathrm{COCl})_{2}, \mathrm{CH}_{2} \mathrm{Cl}_{2}, \mathrm{Et}_{3} \mathrm{~N},-78^{\circ} \mathrm{C}$; b) $\mathrm{CrCl}_{2}, \mathrm{CHI}_{3}, \mathrm{THF} 0{ }^{\circ} \mathrm{C}$

Scheme 4. Takai olefination and preparation of vinylic iodide 22. 
<smiles>CCOC(=O)C(O[SbH3])C([SeH3])CC[SeH3]</smiles>

$(-)-20$

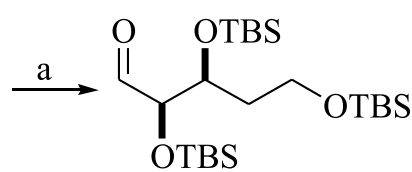

$(-)-23$<smiles>COC(C=CI)C(O[SbH2])O[SbH3]</smiles>

24

a) DIBAL-H, toluene, $-90^{\circ} \mathrm{C}$; b) $\mathrm{CrCl}_{2}, \mathrm{CHI}_{3}$, THF

Scheme 5. Preparation of vinylic iodide 24 .

Table 1. Takai olefination of aldehyde $\mathbf{2 3}$.

\begin{tabular}{cccccc}
\hline Entry & $\mathrm{CrCl}_{2}$ (equiv.) & $\mathrm{CHI}_{3}$ (equi.) & Time (h) & Temp. $\left({ }^{\circ} \mathrm{C}\right)$ & Yield $(\%)^{\mathrm{a}}$ \\
\hline 1 & 6 & 2 & 18 & 0 & $12(24)$ \\
2 & 6 & 2 & 48 & $\mathrm{Rt}$ & $18(50)$ \\
3 & 12 & 4 & 66 & $\mathrm{Rt}$ & 38 \\
4 & 12 & 4 & 66 & 55 & 53 \\
\hline
\end{tabular}

a) yield in parenthesis based on recovered aldehyde.

Upon changing the amounts of $\mathrm{CrCl}_{2}$ (12 equiv.) and iodoform (4 equiv.), iodide $\mathbf{2 4}$ was obtained in $53 \%$ yield when the reaction was carried out at $55^{\circ} \mathrm{C}$ (Table 1).

The reason for the high diastereoselectivity in the Takai olefination of aldehyde $\mathbf{2 3}$ is not totally clear at this point but it can be rationalized through the intervention of the geminal organochromium species $\mathbf{2 5}$, as proposed by Hodgson $^{22}$. The addition of this species to the aldehyde would be followed by syn elimination. The preferential formation of olefin E-28 would arise from the relief of steric interactions between the $\mathrm{R}$ group in $\mathbf{2 3}$ and the iodine atom upon changing conformation $27 \mathbf{a}$ to $\mathbf{2 7} \mathbf{b}$. The corresponding $Z$ olefin would be less favoured due to the expected higher steric energy associated to conformer 27a which displays staggered $\mathrm{R}$ group and iodine (Scheme 6). The presence of bulky TBS groups in the aldehyde would not only enforce conformation $\mathbf{2 7 b}$ but could conceivably slow down the reaction ${ }^{23}$.

With the preparation of the key intermediate $\mathbf{2 4}$ secured, we focused on its conversion to carboxylic acid 7. The primary OTBS group was removed with HF.pyridine to afford the primary alcohol in $64 \%$ yield which was converted to the corresponding carboxylic acid with Jones reagent (79\% yield ${ }^{24,25}$. Considering that partial deprotection of the OTBS group in $\mathbf{2 4}$ was observed during column chromatography on silica gel and the report by Evans e coworkers ${ }^{26}$ on the one-pot primary OTBS deprotection-Jones oxidation sequence, we decided to carry out the oxidation step directly from crude iodide $\mathbf{2 4}$. Ester (-)-20 was reduced to aldehyde 23 and homologated under the condition developed by Takai ${ }^{17}$. Crude iodide was taken up in acetone and treated with Jones reagent at $0{ }^{\circ} \mathrm{C}$ to yield carboxylic acid (-)-7, in $53 \%$ overall yield (3 steps, Scheme 7).

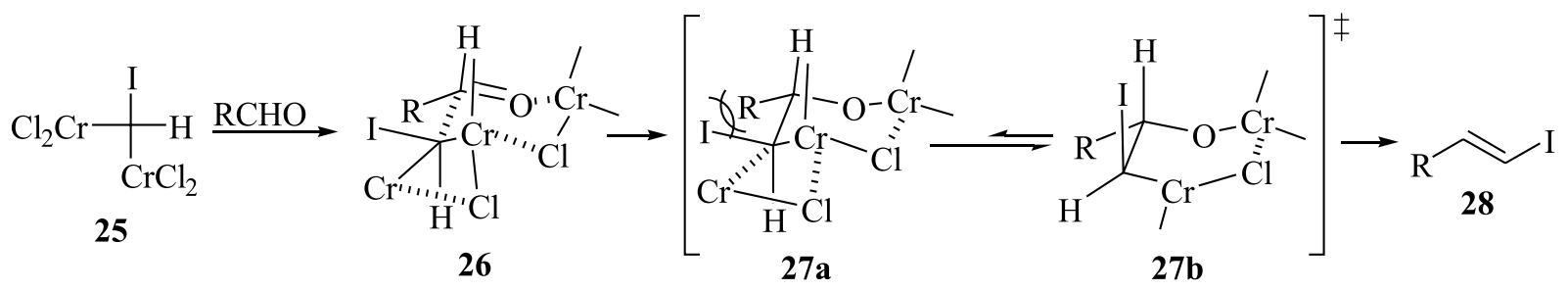

Scheme 6. Mechanistic rationale for the stereoselective formation of $(E)$-vinylic iodide 28.

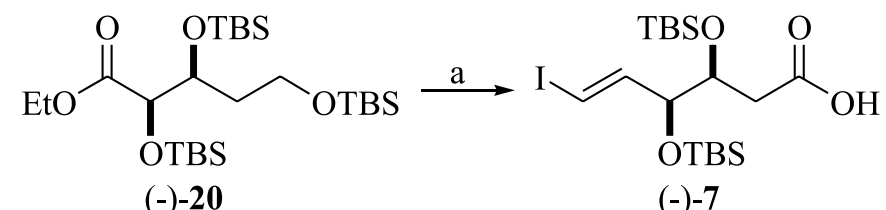

a) (i) DIBAL-H (2.5 eq), toluene, $-95{ }^{\circ} \mathrm{C}, 1 \mathrm{~h}$; (ii) $\mathrm{CrCl}_{2}$ (12 eq.), THF, $55{ }^{\circ} \mathrm{C}$; (iii) Jones reagent, acetone, $0{ }^{\circ} \mathrm{C}(3$ steps, $53 \%$ overall yield). 


\section{The C7-C10 fragment 8}

The preparation of this moiety began with the reduction of PHB (11) with $\mathrm{LiAlH}_{4}{ }^{27}$ to afford diol (-)-29, in $85 \%$ yield. Selective silylation of the primary hydroxyl group afforded (+)-8, in $83 \%$ yield. The enantiomeric excess of this intermediate was determined to be $>99 \%$ ee by GC analysis with chiral column ${ }^{16}$ (Scheme 8).

\section{Coupling of the C1-C6 and C7-C10 fragments}

Our expectation to control the stereogenic center to be created at C7 was based on the interplay of transannular interactions, known to be proeminent in medium-size rings $^{28}$, and on the proposal by Overman and coworkers of a well organized arrangement in the transition state of the Nozaki-Hiyama-Kishi reaction. During the synthesis of (-)-7-deacetoxyalcionine ${ }^{29}$, Overman and coworkers proposed the chelation of the vinylic chromium species to the carbonyl of the aldehyde to explain the outstanding diastereoselectivity observed in the formation of the 9membered ring (>20:1). Carbonyl facial selection would then be dictated by a preferential endo positioning of the hydrogen in the formyl group of the aldehyde to minimize transannular interactions.

As applied to our case, the ideas above allow one to expect that:

i) the methyl group at $\mathrm{C} 9$ would adopt a pseudo-equatorial orientation in the transition state thus determining the relative position of the $\mathrm{C} 9-\mathrm{C} 7$ moiety and influencing carbonyl facial selection;

ii) the judicious choice of the protecting group at the oxygens atoms at $\mathrm{C} 3$ and $\mathrm{C} 4$ could dictate the relative positioning of the $\mathrm{C} 5-\mathrm{C} 6$ and $\mathrm{C} 2-\mathrm{O}-\mathrm{C} 7$ fragments (Figure 1): OTBS protecting groups which are bound to adopt anti relative orientation would enforce gauche orientation (conformation A) while isopropylideneacetal as protecting

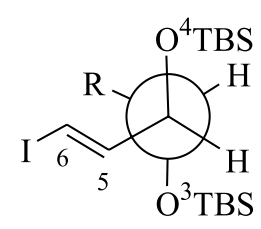

Conformation A

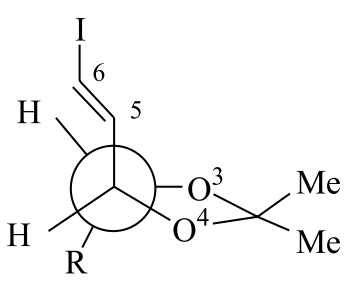

Conformation B
Figure 1. Conformational bias imposed by the protecting groups.

group would keep the side chains apart (conformation B).

The coupling of the C1-C6 and C7-C10 fragments was carried out with Yamaguchi protocol ${ }^{30}$ : carboxylic acid (-)-7 was previously treated with 2,4,6-trichlorobenzoyl chloride and the mixed anhydride formed was reacted with alcohol (+)-8. Ester (-)-30 was isolated in $83 \%$ yield (Scheme 9).

In order to test our working hypothesis, alcohol (-)-35 was prepared from (-)-30: removal of the primary OTBS group afforded unstable alcohol $\mathbf{3 1}$ which was immediately protected as the PMB ether to afford (-)-32 in 74\% overall yield (two steps) ${ }^{31}$. The secondary hydroxyl groups at $\mathrm{C} 3$ e C4 were removed with a large excess of HF.pyridine complex and the unstable diol $\mathbf{3 3}$ was immediately protected as the corresponding isopropylidene acetal with dimethoxypropane and catalytic PPTS in DMF to afford (-)-34 in $85 \%$ overall yield (two steps) ${ }^{32}$. Oxidative cleavage of the PMB ether ${ }^{33}$ provided alcohol (-)-35, in $70 \%$ yield. Surprisingly, alcohol (-)-35 turned out to be rather stable as compared to alcohol $\mathbf{3 1}$ as no sign of transesterification was detected by ${ }^{1} \mathrm{H}-\mathrm{NMR}$ even after monitoring the same sample in $\mathrm{CDCl}_{3}$ for 7 days. Such behaviour was assigned to conformational changes upon changing from a sterically demanding protecting group (OTBS) to a conformationally constrained one (isopropylidene acetal).<smiles>CC(O)CC[R15](C)(C)C(=O)C[C@@H]1C[C@H](C)O1</smiles>

a) $\mathrm{LiAlH}_{4}$, THF, reflux, 5h (85\%); b) TBSCl, Et 3 N, DMAP, $\mathrm{CH}_{2} \mathrm{Cl}_{2}, 0{ }^{\circ} \mathrm{C}, 1 \mathrm{~h}(83 \%)$

Scheme 8. Preparation of the C7-C10 fragment 8 from polyhydroxybutyrate (11). 


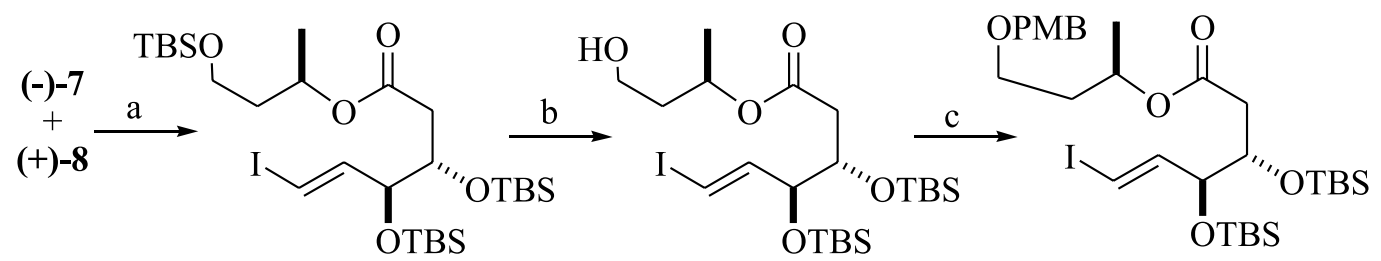

$(-)-30$<smiles>CC(C)OCCC(C)OC(=O)C[C@@H](O)C(O)/C=C/I</smiles>

33<smiles>CC(CCOC(C)(C)C)OC(=O)C[C@H]1OC(C)(C)O[C@@H]1/C=C/I</smiles>

$(-)-34$<smiles>CC(CCO)OC(=O)C[C@H]1OC(C)(C)O[C@@H]1/C=C/I</smiles>

(-)-35

a) i) (-)-7, 2,4,6-trichlorobenzoyl chloride, THF, Et ${ }_{3} \mathrm{~N}$; ii) (+)-8, benzene, DMAP (83\%); b) HF.pyridine, THF, 3h; c) PMB trichloroacetimidate, TfOH (cat.), $\mathrm{Et}_{2} \mathrm{O}, 30 \mathrm{~min}$ (53\% for two steps); d) HF.pyridine pyridine, THF, 3h; e) 2,2-dimethoxypropane, PPTS, DMF, $24 \mathrm{~h}$ (77\% for two steps); f) DDQ, $\mathrm{CH}_{2} \mathrm{Cl}_{2}, \mathrm{H}_{2} \mathrm{O}, 30 \mathrm{~min}(70 \%)$.

Scheme 9. The coupling of fragments (-)-7 and (+)-8.

The macrolactonization step: stereoselective NozakiHiyama-Kishi cyclization (NHK)

At this point we were ready to apply the intramolecular NHK reaction to the aldehydes derived from conformationally biased alcohols $\mathbf{3 1}$ and $\mathbf{3 5}$. Due to the labile nature of alcohol 31, a method was sought to oxidize it as soon as it was liberated from (-)-30: our first choice was the use of Swern conditions [i) $(\mathrm{COCl})_{2}$, DMSO, $\mathrm{CH}_{2} \mathrm{Cl}_{2}$,- $78^{\circ} \mathrm{C}$; ii) $\mathrm{Et}_{3} \mathrm{~N}$, rt] which led mainly to carboxylic acid (-)7 through base-promoted elimination, probably at the aldehyde stage. We were then forced to try Dess-Martin periodinane ${ }^{34}$ which only circumvented the formation of (-)-7 and efficiently provided aldehyde 36 when the modified conditions described by Meyer and Schreiber ${ }^{34 c}$ were employed (Scheme 10).

Aldehyde 36 was not purified but immediately used in the NHK step. After extensive experimentation the best<smiles>C[C@H](CCO)OC(=O)C[C@H](O)[C@@H](/C=C/I)O[GaH]</smiles>

$$
\begin{aligned}
& \mathbf{3 1} \mathrm{P}^{1}=\mathrm{P}^{2}=\text { TBS } \\
& (-)-\mathbf{3 5} \mathrm{P}^{1}=\mathrm{P}^{2}=\mathrm{CMe}_{2}
\end{aligned}
$$<smiles>C[CH]CC(=O)C[C@H](C)OC(=O)C[C@H]([O])[C@H](O)/C=C/I</smiles>

$36 \mathrm{P}^{1}=\mathrm{P}^{2}=\mathrm{TBS}$ $37 \mathrm{P}^{1}, \mathrm{P}^{2}=\mathrm{CMe}_{2}$

a) Dess-Martin periodinane, $\mathrm{CH}_{2} \mathrm{Cl}_{2}, \mathrm{H}_{2} \mathrm{O}$ (cat.);

b) $\mathrm{CrCl}_{2}, \mathrm{NiCl}_{2}$ (cat.), $\mathrm{DMF}\left(0.005 \mathrm{~mol} \mathrm{~L}^{-1}\right)$, rt.

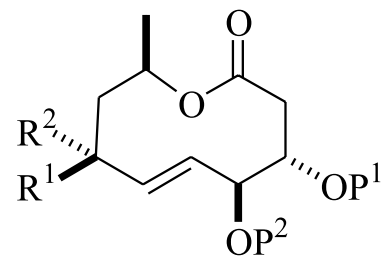

(-)-38a $\mathrm{P}^{1}=\mathrm{P}^{2}=$ TBS $\mathrm{R}^{1}=\mathrm{OH}, \mathrm{R}^{2}=\mathrm{H}$ 38b $\mathrm{P}^{1}=\mathrm{P}^{2}=\mathrm{OTBS}$, $\mathrm{R}^{1}=\mathrm{H}, \mathrm{R}^{2}=\mathrm{OH}$

39a $\mathrm{P}^{1}, \mathrm{P}^{2}=\mathrm{CMe}_{2}$, $\mathrm{R}^{1}=\mathrm{OH}, \mathrm{R}^{2}=\mathrm{H}$ 39b $\mathrm{P}^{1}, \mathrm{P}^{2}=\mathrm{CMe}_{2}$, $\mathrm{R}^{1}=\mathrm{H}, \mathrm{R}^{2}=\mathrm{OH}$ 
protocol required the use of 15 equiv. of $\mathrm{CrCl}_{2}$ in degassed DMF at room temperature which afforded decanolide (-)38a as a single isomer in $30 \%$ overall yield (3 steps) from ester (-)-30. Attempts to improve the yield without decrease of the diastereoselectivity were not successfull as the use of DMSO as solvent afforded similar overall yield (35\%) but a 2:1 mixture of (-)-38a and $\mathbf{3 8 b}$ (C-7 epimer), as determined by ${ }^{1} \mathrm{H}$ NMR of the crude mixture. Modification in the workup of the reaction (use of triethanolamine or ethylenediamine to complex chromium salts) or the use of modified conditions for the chromium-mediated Reformatzky reation ${ }^{35}$ were not successfull. The above reaction condition was applied to alcohol (-)-35 and decanolides 39a and 39b were isolated in $41 \%$ yield (two steps) as a 1:2 mixture ( $\left.{ }^{1} \mathrm{H} \mathrm{NMR}\right)$.

At this point we were not able to carry out an unambiguous assignement of (-)-38a but its ${ }^{1} \mathrm{H}-\mathrm{NMR}$ data suggested the $7 \mathrm{~S}$ configuration: $\mathrm{H}-7$ appeared as a triple doublet at $\delta 4.21$ with two large coupling constants (10.8 and $8.4 \mathrm{~Hz})$ and a small one $(3.4 \mathrm{~Hz})$. The two large coupling constants were assigned to its trans orientation to H-6 and H-8 in chair-chair-chair conformation of (-)38a while the small one was due to $\mathrm{H}-8_{\text {eq }}$. Such assignment was supported by some nOe experiments: a $4.3 \%$ increment at H-7 was observerd upon irradiation of H-9 $(\delta 5.08)$

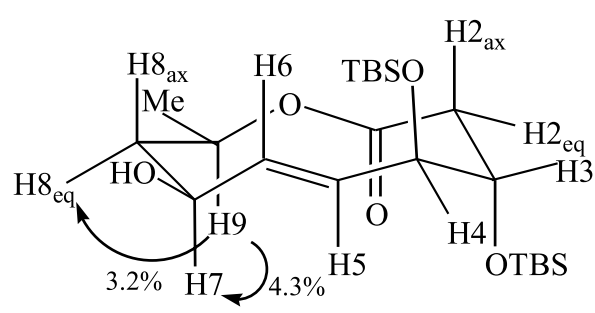

Figure 2. Chair-chair-conformation and nOe increments for decanolide 38a.
In the spectra of the isopropylidene derivatives 39a and 39b, $\mathrm{H}-7$ appeared as a multiplet and the information on the relative configuration of this stereogenic center had to be retrieved from the data of $\mathrm{H}-8$ and $\mathrm{H}-6$ : in the major diastereoisomer 39b, $\mathrm{H}-8 \mathrm{ax}$ appeared as a triple doublet at $\delta 1.87$ with two large $\left({ }^{2} J 14.9\right.$ and $\left.{ }^{3} J\left(H 8_{\text {ax }}-\mathrm{H} 7\right) 7.3 \mathrm{~Hz}\right)$ and a small one ( $\left.{ }^{3} \mathrm{~J}\left(\mathrm{H} 8_{\mathrm{ax}}-\mathrm{H} 9_{\mathrm{eq}}\right) 3.7 \mathrm{~Hz}\right)$ while $\mathrm{H}-6$ displayed a double doublet at $\delta 5.69$ with two large coupling constants in 39b ( ${ }^{3} J 16.4$ and $\left.7.3 \mathrm{~Hz}\right)$ and appeared as a multiplet in minor 39a. Additionally, isomers 39a and 39b could not be separated by chromatography on silicagel and only circunstancial evidence on the sterochemical assignement at C-7 could be provided at this stage for 39a and 39b.

The final proof of the $7 S$ configuration of (-)-38a came from its conversion to (-)-decarestrictine D (1). Tetrabutylammonium fluoride (TBAF) and acetic acid in $\mathrm{THF}^{36}$ led to recovery of (-)-38a even after $24 \mathrm{~h}$ at room temperature while the use of hydrofluoric acid in acetonitrile-water mixture led to extensive decomposition. We reasoned that the acid lability of $\mathbf{1}$ would call for a buffered medium. We turned our attention to the HF.pyridine complex which provided 1 but only in $10 \%$ yield after $24 \mathrm{~h}$ at room temperature with recovery of (-)- $\mathbf{3 8 a}$ and, finally, to a mixture of TBAF-HF in acetonitrile-water which successfully provided 1 in $83 \%$ yield, after $2.5 \mathrm{~h}$ at room temperature (Scheme 11).

The authenticity of synthetic (-)-decarestrictine $\mathrm{D}\left([\alpha]_{\mathrm{D}}\right.$ -70.9 ( $c 0.24, \mathrm{CHCl}_{3}$; lit. ${ }^{\mathrm{la}}\left([\alpha]_{\mathrm{D}}-67.0\left(c 0.26, \mathrm{CHCl}_{3}\right)\right)$ was secured after comparison of its spectroscopic data with those described by Zeeck ${ }^{1 \mathrm{a}}$ and Andrus ${ }^{3}$.

In conclusion, the total synthesis of $\mathbf{1}$ was achieved in 13 steps and $6.3 \%$ overall yield from 1,3-propanediol and provided the opportunity to uncover the effect of local conformations on the stereochemical outcome of the Nozaki-Hiyama-Kishi intramolecular cyclization as applied to the formation of 10-membered lactones. Further studies are underway in order to collect more data on such effects.

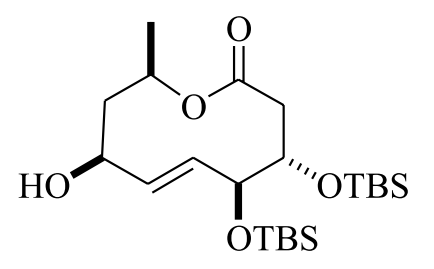

$(-)-37$<smiles>CC(O)CC(O)C=CC(O)[C@H](O)CC(=O)O</smiles>

$(-)-1$

a) TBAF, $40 \%$ aq. $\mathrm{HF}, \mathrm{CH}_{3} \mathrm{CN}$, rt (83\%).

Scheme 11. Final step in the total synthesis of (-)-decarestrictine D (1). 


\section{Experimental}

\section{General}

Melting points are uncorrected. Unless otherwise stated, all reactions were carried out under a nitrogen atmosphere. Anhydrous solvents were freshly distilled before use: diethyl ether and tetrahydrofuran (THF) from sodium benzophenone ketyl, benzene from sodium and stored over $4 \AA$ Å molecular sieves, methylene chloride and triethylamine from $\mathrm{CaH}_{2}$. Dimethylformamide was treated with $\mathrm{P}_{2} \mathrm{O}_{5}$, distilled from $\mathrm{CaH}_{2}$ and stored over $4 \AA$ molecular sieves. $\mathrm{CrCl}_{2}$ containing $0.5 \% \mathrm{~mol} \mathrm{NiCl}_{2}$ was activated $4 \mathrm{~h}$ at $250^{\circ} \mathrm{C}$ under vacuum (1 $\mathrm{mmHg})$ and weighted under argon atmosphere in a glovebox. The remaining reagents were purchased from commercial suppliers and used without further purification. ${ }^{1} \mathrm{H}$ NMR spectra were recorded at 300 or $500 \mathrm{MHz} ;{ }^{13} \mathrm{C} \mathrm{NMR} \mathrm{spectra} \mathrm{were} \mathrm{recorded} \mathrm{at} 75$ or 125 $\mathrm{MHz}$. Residual $\mathrm{CHCl}_{3}(\delta$ 7.26) was used as an internal standart in ${ }^{1} \mathrm{H}$ NMR spectra. ${ }^{13} \mathrm{C}$ NMR spectra were referenced to $\mathrm{CDCl}_{3}$ at $\delta$ 77.0. Optical rotations were measured at $25^{\circ} \mathrm{C}$ in a Polamat A (Carl Zeiss) polarimeter at $546 \mathrm{~nm}$ (mercury line). Infrared spectra were recorded as films in $\mathrm{KBr}$ cells on with Nicolet Impact 410 spectrophotometer, unless otherwise stated. GC-MS analyses were performed on a Hewlett-Packard 5890 series II gas chromatograph coupled to a MSD 5970 mass detector. High resolution mass spectra were obtained via electron impact $(70 \mathrm{eV})$ on a VG Autospec spectrometer. Column chromatography was performed using silica gel (70-230 Mesh), except when stated otherwise. Gradients of EtOAc and n-hexane were used as eluents and reactions were monitored by TLC (plates from Macherey-Nagel, Germany).

\section{3-tert-Butyldimethylsilyloxy-1-propanol (16)}

$\mathrm{NaH}$ (0.785 g, $32.7 \mathrm{mmol} ; 60 \%$ in mineral oil), previously washed with hexane, was suspended in THF $\left(70 \mathrm{~cm}^{3}\right)$. A solution of 1,3-propanediol 15 (2.49 g, 32.7 $\mathrm{mmol})$ in THF $\left(10 \mathrm{~cm}^{3}\right)$ was added to this suspension at room temperature and stirred $45 \mathrm{~min}$ until a large quantity of a white solid has been formed. TBSCl (4.93 g, 32.7 $\mathrm{mmol}$ ) was added and vigorous stirring was continued for $45 \mathrm{~min}$. The mixture was diluted with $\mathrm{Et}_{2} \mathrm{O}\left(150 \mathrm{~cm}^{3}\right)$ and successively treated with $\mathrm{K}_{2} \mathrm{CO}_{3} 10 \%\left(120 \mathrm{~cm}^{3}\right)$, brine $(100$ $\mathrm{cm}^{3}$ ), dried over $\mathrm{MgSO}_{4}$ and concentrated in vacuo, furnished the monoprotected diol $15(5.67 \mathrm{~g}, 91 \%)$ as a colorless oil. IR $v_{\max } / \mathrm{cm}^{-1} 3355 ;{ }^{1} \mathrm{H} \mathrm{NMR}\left(300 \mathrm{MHz}, \mathrm{CDCl}_{3}\right)$ $\delta 3.84(\mathrm{t}, J 5.5 \mathrm{~Hz}, 2 \mathrm{H}), 3.81(\mathrm{t}, J 5.5 \mathrm{~Hz}, 2 \mathrm{H}), 2.60$ (s, br, 1H), 1.77 (quint, $J 5.5 \mathrm{~Hz}, 2 \mathrm{H}), 0.89$ (s, 9H), 0.07 (s, 6H);
${ }^{13} \mathrm{C} \mathrm{NMR}\left(75 \mathrm{MHz}, \mathrm{CDCl}_{3}\right) \delta 62.8,62.2,34.2,25.8,-5.5$ (x2).

Ethyl (E)-5-(tert-butyldimethylsilyloxy)-2-pentenoate $(10 E)$

To a stirred solution of oxalyl chloride $\left(0.60 \mathrm{~cm}^{3}, 6.9\right.$ mmol) in $\mathrm{CH}_{2} \mathrm{Cl}_{2}\left(10.3 \mathrm{~cm}^{3}\right)$ at $-78^{\circ} \mathrm{C}$ was added DMSO $\left(1.00 \mathrm{~cm}^{3}, 13.9 \mathrm{mmol}\right)$. After 5 minutes, alcohol $16(0.660$ $\mathrm{g}, 3.47 \mathrm{mmol})$ in $\mathrm{CH}_{2} \mathrm{Cl}_{2}\left(10.3 \mathrm{~cm}^{3}\right)$ was added dropwise. The mixture was stirred at $-78{ }^{\circ} \mathrm{C} 1 \mathrm{~h}$ and $\mathrm{Et}_{3} \mathrm{~N}\left(2.70 \mathrm{~cm}^{3}\right.$, $19.7 \mathrm{mmol}$ ) was added and the solution was allowed to reach room temperature. The mixture was successively treated with aqueous $5 \% \mathrm{HCl}\left(25 \mathrm{~cm}^{3}\right)$, water $\left(25 \mathrm{~cm}^{3}\right)$, brine $\left(25 \mathrm{~cm}^{3}\right)$, dried over $\mathrm{MgSO}_{4}$ and concentrated. The crude aldehyde $(0.370 \mathrm{~g})$ was used in the next step without further purification.

To a stirred suspension of $\mathrm{NaH}(0.125 \mathrm{~g} ; 5.20 \mathrm{mmol}$; $60 \%$ in mineral oil previously washed with hexane) in THF $\left(10.4 \mathrm{~cm}^{3}\right)$ at $0^{\circ} \mathrm{C}$ was added dropwise triethylphosphonoacetate $18\left(1.03 \mathrm{~cm}^{3}, 1.17 \mathrm{~g}, 5.20 \mathrm{mmol}\right)$. After $15 \mathrm{~min}$, a solution of crude aldehyde in THF $\left(10.4 \mathrm{~cm}^{3}\right)$ was added dropwise. The reaction was allowed to reach room temperature and stirred for additional $2.5 \mathrm{~h}$, diluted with $\mathrm{Et}_{2} \mathrm{O}\left(60 \mathrm{~cm}^{3}\right)$ and successively washed with water $\left(10 \mathrm{~cm}^{3}\right)$, brine $\left(10 \mathrm{~cm}^{3}\right)$, dried over $\mathrm{MgSO}_{4}$ and concentrated. Silica gel chromatography (EtOAc:hexane 1:99, v/v) furnished $\mathbf{1 0 E}(0.614 \mathrm{~g}, 69 \%)$ and its isomer $10 Z(0.034 \mathrm{~g}, 4 \%)$. (10E): IR $v_{\max } / \mathrm{cm}^{-1} 1724,1657 ;{ }^{1} \mathrm{H}$ NMR $(300 \mathrm{MHz}$, $\left.\mathrm{CDCl}_{3}\right) \delta 6.96(\mathrm{dt}, J 16.0,7.0 \mathrm{~Hz}, 1 \mathrm{H}), 5.86(\mathrm{dt}, J$ 16.0, $1.5 \mathrm{~Hz}, 1 \mathrm{H}), 4.19$ (q, J 7.2 Hz, 2H), 3.73 (t, J $6.5 \mathrm{~Hz}, 2 \mathrm{H})$, $2.41(\mathrm{dq}, J \quad 6.5,1.5 \mathrm{~Hz}, 2 \mathrm{H}), 1.28(\mathrm{t}, J 7.2 \mathrm{~Hz}, 3 \mathrm{H}), 0.89$ $(\mathrm{s}, 9 \mathrm{H}), 0.05(\mathrm{~s}, 6 \mathrm{H}) ;{ }^{13} \mathrm{C} \mathrm{NMR}\left(75 \mathrm{MHz}, \mathrm{CDCl}_{3}\right) \delta 166.4$, 145.8, 122.9, 61.5, 60.1, 35.7, 25.8, 18.3, 14.2, -5.4 (x2); MS (EI) $m / z 73(100 \%), 201\left(86 \%,\left[\mathrm{M}-\mathrm{C}_{4} \mathrm{H}_{9}\right]^{+}\right)$; HRMS (EI): found 201.09275; calc. for $\mathrm{C}_{9} \mathrm{H}_{17} \mathrm{O}_{3} \mathrm{Si}\left[\mathrm{M}-\mathrm{C}_{4} \mathrm{H}_{9}\right]^{+}$ 201.09470; (10Z): IR $v_{\max } / \mathrm{cm}^{-1} 1722 ;{ }^{1} \mathrm{H}$ NMR $(300 \mathrm{MHz}$, $\left.\mathrm{CDCl}_{3}\right) \delta 6.34(\mathrm{dt}, J 11.5,7.0 \mathrm{~Hz}, 1 \mathrm{H}), 5.83(\mathrm{dt}, J 11.5$, $1.7 \mathrm{~Hz}, 1 \mathrm{H}), 4.16(\mathrm{q}, J 7.1 \mathrm{~Hz}, 2 \mathrm{H}), 3.71(\mathrm{dt}, J 9.0,6.0 \mathrm{~Hz}$, 2H), 2.87 (dq, J 7.0, 1.7 Hz, 2H), 1.29 (t, J 7.1 Hz, 3H), $0.89(\mathrm{~s}, 9 \mathrm{H}), 0.05(\mathrm{~s}, 6 \mathrm{H}) ;{ }^{13} \mathrm{C} \mathrm{NMR}\left(75 \mathrm{MHz} \mathrm{CDCl}_{3}\right)$ $\delta 166.4,147.1,120.8,62.0,59.8,32.5,25.9,18.3,14.2$, $-5.4(\mathrm{x} 2)$.

Ethyl (2R,3S)-5-(tert-butyldimethylsilyloxy)-2,3-dihydroxypentanoate (19)

To a vigorously stirred mixture containing $t$ - $\mathrm{BuOH}(14.8$ $\mathrm{cm}^{3}$ ), water $\left(14.8 \mathrm{~cm}^{3}\right)$ and AD-mix $\alpha^{\circledR}(4.16 \mathrm{~g})$ was added at room temperature metanesulfonamide $(0.283 \mathrm{~g}, 2.97$ mmol). The orange mixture was cooled at $0^{\circ} \mathrm{C}$ and olefin 
$\mathbf{1 0 E}(0.767 \mathrm{~g}, 2.97 \mathrm{mmol})$ was added and allowed to stir 24 $\mathrm{h}$ at $0^{\circ} \mathrm{C}$. The reaction was quenched with $\mathrm{Na}_{2} \mathrm{SO}_{3}(4.46 \mathrm{~g})$, allowed to warm up to room temperature and stirred $1 \mathrm{~h}$ at this temperature. The reaction mixture was diluted with $\mathrm{CH}_{2} \mathrm{Cl}_{2}\left(50 \mathrm{~cm}^{3}\right)$ and the layers were separated. The aqueous layer was extracted with $\mathrm{CH}_{2} \mathrm{Cl}_{2}\left(4 \times 20 \mathrm{~cm}^{3}\right)$, the combined organic layers were washed with $\mathrm{KOH} 2 \mathrm{~mol} \mathrm{~L}-1\left(40 \mathrm{~cm}^{3}\right)$, brine $\left(40 \mathrm{~cm}^{3}\right)$, dried over $\mathrm{MgSO}_{4}$ and concentrated under reduced pressure. Silica gel chromatography (EtOAc:hexane 30:70, v/v) furnished diol (-)-19 $(0.817 \mathrm{~g}, 94 \%)$ as a colorless oil. $[\alpha]_{546}-24.6$ (c 1.23, EtOH); IR $v_{\max } / \mathrm{cm}^{-1} 3469,1743 ;{ }^{1} \mathrm{H}$ NMR (300 MHz, $\left.\mathrm{CDCl}_{3}\right) \delta 4.28(\mathrm{q}, J 7.1 \mathrm{~Hz}, 2 \mathrm{H}), 4.17$ (ddd, J 9.0, 3.5, 2.0 Hz, 1H), 4.05 (d, J 2.0 Hz, 1H), 3.87 (m, 2H), 3.19-3.25 (br s 2H), 1.95 (dtd, J 14.5, 9.0, $4.5 \mathrm{~Hz}$, 1H), 1.73 (ddt, J 14.5, 5.5, $3.5 \mathrm{~Hz}, 1 \mathrm{H}), 1.31(\mathrm{t}, J 7.1 \mathrm{~Hz}$, $3 \mathrm{H}), 0.89$ (s, 9H), 0.07 (s, 6H); ${ }^{13} \mathrm{C} \mathrm{NMR}\left(75 \mathrm{MHz}, \mathrm{CDCl}_{3}\right)$ $\delta$ 173.1, 73.6, 72.1, 61.8, 61.6, 35.2, 25.8, 18.1, 14.1, -5.6 (x2); MS (EI) $m / z 75$ (100\%), 235 (30\%, [M-C $\left.\left.\mathrm{H}_{9}\right]^{+}\right)$; HRMS (EI): found 235.10014; calc. for $\mathrm{C}_{9} \mathrm{H}_{19} \mathrm{O}_{5} \mathrm{Si}$ : $\left[\mathrm{M}-\mathrm{C}_{4} \mathrm{H}_{9}\right]^{+}$ 235.10018 .

Ethyl (2R,3S)-2,3,5-tris-(tert-butyldimethylsilyloxy)pentanoate (20)

To a solution of diol (-)-19 (0.799 $\mathrm{g}, 2.73 \mathrm{mmol})$ in DMF $\left(1.60 \mathrm{~cm}^{3}\right)$ were added imidazole $(0.930 \mathrm{~g}, 13.7$ $\mathrm{mmol})$ and $\mathrm{TBSCl}(0.988 \mathrm{~g}, 6.55 \mathrm{mmol})$. The reaction was stirred $48 \mathrm{~h}$ at room temperature, diluted with $\mathrm{Et}_{2} \mathrm{O}(10$ $\left.\mathrm{cm}^{3}\right)$ and quenched by the addition of brine $\left(20 \mathrm{~cm}^{3}\right)$. After phase separation, the aqueous phase was extracted with $\mathrm{CH}_{2} \mathrm{Cl}_{2}\left(3 \mathrm{X} 10 \mathrm{~cm}^{3}\right)$. The combined organic layer was dried over $\mathrm{Na}_{2} \mathrm{SO}_{4}$ and concentrated under reduced pressure. Silica gel chromatography (AcOEt:hexane 15:85, $\mathrm{v} / \mathrm{v})$ furnished (-)-20 $(1.250 \mathrm{~g}, 99 \%)$ as a colorless oil. $[\alpha]_{546}$ -20.0 (c 1.0, EtOH); IR $v_{\text {max }} / \mathrm{cm}^{-1} 1751 ;{ }^{1} \mathrm{H} \mathrm{NMR}(300 \mathrm{MHz}$, $\left.\mathrm{CDCl}_{3}\right) \delta 4.15(\mathrm{~m}, 3 \mathrm{H}), 4.05(\mathrm{dt}, J 8.5,4.0 \mathrm{~Hz}, 1 \mathrm{H}), 3.67$ (dd, $J$ 7.5, 2.0 Hz, 2H), 1.98 (dtd, $J 13.5,7.5,4.0 \mathrm{~Hz}, 1 \mathrm{H}$ ), 1.54 (ddt, $J$ 13.5, 8.5, 5.0 Hz, 1H), 1.27 (t, $J$ 7.1 Hz, 3H), 0.91 (s, 9H), 0.89 (s, 9H), 0.88 (s, 9H), 0.07 (s, 6H), 0.06 $(\mathrm{s}, 3 \mathrm{H}), 0.05(\mathrm{~s}, 3 \mathrm{H}), 0.04(\mathrm{~s}, 6 \mathrm{H}) ;{ }^{13} \mathrm{C} \mathrm{NMR}(75 \mathrm{MHz}$, $\left.\mathrm{CDCl}_{3}\right) \delta 171.0,74.7,70.8,60.4,59.3,35.2,25.9,25.7$ (x2), 18.2 (x2), 18.0, 14.2, -4.6, -4.7, -4.9, -5.2, -5.3, -5.4; MS (EI): $m / z 463\left(100 \%,\left[\mathrm{M}-\mathrm{C}_{4} \mathrm{H}_{9}\right]^{+}\right)$; HRMS (EI): found 417.27264 $\left.\left(\mathrm{M}-\mathrm{C}_{4} \mathrm{H}_{9}\right]^{+}\right)$; calc. for $\mathrm{C}_{21} \mathrm{H}_{47} \mathrm{O}_{5} \mathrm{Si}_{3}: 463.27314$.

(3S,4S,5E)-3,4-bis-(tert-Butyldimethylsilyloxy)-6-iodo-5hexenoic acid (7)

To a solution of ester (-)-20 (0.582 $\mathrm{g}, 1.12 \mathrm{mmol})$ in toluene $\left(2.3 \mathrm{~cm}^{3}\right)$ at $-95^{\circ} \mathrm{C}$ (liquid $\mathrm{N}_{2} /$ hexane bath) was added dropwise a $1.0 \mathrm{~mol} \mathrm{~L}{ }^{-1}$ DIBAL-H soln. in hexane $\left(2.3 \mathrm{~cm}^{3}, 2.3 \mathrm{mmol}\right)$. The reaction mixture was stirred for $1 \mathrm{~h}$ at $-95^{\circ} \mathrm{C}$, quenched with ethyl acetate $\left(3.96 \mathrm{~cm}^{3}\right)$, followed by addition of a saturated solution of sodium and potassium tartrate $\left(4.0 \mathrm{~cm}^{3}\right)$. The reaction mixture was allowed to warm to room temperature and stirred $2 \mathrm{~h}$ at this temperature. Addition of $\mathrm{Et}_{2} \mathrm{O}\left(10 \mathrm{~cm}^{3}\right)$ was followed by phase separation. The aqueous phase was further extracted with $\mathrm{Et}_{2} \mathrm{O}\left(4 \times 5 \mathrm{~cm}^{3}\right)$, the combined organic layers were concentrated under reduced pressure, and the residue was filtered through Celite. Evaporation under reduced pressure afforded crude aldehyde $\mathbf{2 3}$ which was used in the next step without further purification.

To a suspension of $\mathrm{CrCl}_{2}(1.62 \mathrm{~g}, 13.2 \mathrm{mmol})$ in THF $\left(36 \mathrm{~cm}^{3}\right)$ were added via cannula a solution of iodoform (1.76 g, $4.47 \mathrm{mmol}$ ) and crude aldehyde 23 in THF (12 $\left.\mathrm{cm}^{3}\right)$. The reaction mixture was stirred and warmed at 55$60^{\circ} \mathrm{C}$ for $48 \mathrm{~h}$. The reaction was quenched with brine ( 60 $\left.\mathrm{cm}^{3}\right)$, and diluted with $\mathrm{Et}_{2} \mathrm{O}\left(60 \mathrm{~cm}^{3}\right)$. The organic layer was separated, and the aqueous one was extracted with $\mathrm{Et}_{2} \mathrm{O}$ until all iodoform has been extracted. The combined organic layers were washed with a $1 \mathrm{~mol} \mathrm{~L}^{-1} \mathrm{Na}_{2} \mathrm{~S}_{2} \mathrm{O}_{3}(30$ $\left.\mathrm{cm}^{3}\right)$, brine $\left(30 \mathrm{~cm}^{3}\right)$, and dried over $\mathrm{MgSO}_{4}$. Evaporation under reduced pressure afforded crude iodide $\mathbf{2 4}$ which was used in the next step without further purification.

A stirred ice-cold acetone solution $\left(43 \mathrm{~cm}^{3}\right)$ of crude iodide 24 was treated dropwise with $8 \mathrm{~mol} \mathrm{~L}^{-1}$ Jones reagent. The excess of the Jones reagent was quenched by the addition of 2-propanol and the mixture was allowed to reach room temperature. The clear greenish solution was decanted and the remaining chromium salts were extracted with $\mathrm{Et}_{2} \mathrm{O}(4 \mathrm{x}$ $\left.10 \mathrm{~cm}^{3}\right)$. The combined extracts were washed with brine (20 $\mathrm{cm}^{3}$ ) and dried over $\mathrm{MgSO}_{4}$. The solvents were removed in vacuum and the remaining crude product was purified by column chromatography (EtOAc:hexane 10:90, v/v) to give carboxilic acid (-)-7 (0.299 g, 53\% overall) as a viscous oil. $[\alpha]_{546}-52.9$ (c 1.7, EtOH); IR $v_{\max } / \mathrm{cm}^{-1} 3500-2500,1716$, 1608; ${ }^{1} \mathrm{H}$ NMR (300 MHz, $\mathrm{CDCl}_{3}$ ) $\delta 6.67$ (dd, J 14.5, 4.0 $\mathrm{Hz}, 1 \mathrm{H}), 6.30$ (dd, J 14.5, $1.5 \mathrm{~Hz}, 1 \mathrm{H}), 4.18-4.08$ (m, 2H), $2.63(\mathrm{dd}, J 16.0,3.0 \mathrm{~Hz}, 1 \mathrm{H}), 2.25$ (dd, $J 16.0,8.0 \mathrm{~Hz}, 1 \mathrm{H})$, 0.89 (s, 9H), 0.88 (s, 9H), 0.09 (s, 3H), 0.07 (s, 3H), 0.06 (s, $3 \mathrm{H}), 0.05(\mathrm{~s}, 3 \mathrm{H}) ;{ }^{13} \mathrm{C} \mathrm{NMR}\left(75 \mathrm{MHz}, \mathrm{CDCl}_{3}\right) \delta 178.5,144.2$, 77.1, 76.2, 71.8, 36.6, 25.5 (x2), 17.8, 17.7, -5.0, -5.2, -5.3,

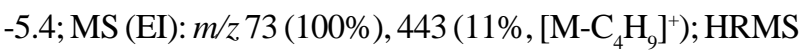
(EI): found 443.05715; calc. for $\mathrm{C}_{14} \mathrm{H}_{28} \mathrm{O}_{4} \mathrm{Si}_{2} \mathrm{I}\left[\mathrm{M}-\mathrm{C}_{4} \mathrm{H}_{9}\right]^{+}$ 443.05709 .

\section{(R)-1,3-Butanediol (29)}

To a suspension of $\mathrm{LiAlH}_{4}(0.200 \mathrm{~g}, 5.27 \mathrm{mmol})$ in THF $\left(9.2 \mathrm{~cm}^{3}\right)$ at $15{ }^{\circ} \mathrm{C}$ was added portionwise polyhydroxybutyrate (PHB) 11 (0.600 g, $6.97 \mathrm{mmol})$. The 
reaction mixture was stirred for $2 \mathrm{~h}$ at room temperature, refluxed $5 \mathrm{~h}$ and allowed to stir overnight at room temperature. The reaction mixture was cooled at $0{ }^{\circ} \mathrm{C}$ and successively treated with water $\left(0.2 \mathrm{~cm}^{3}\right), 10 \%$ aqueous $\mathrm{NaOH}\left(0.2 \mathrm{~cm}^{3}\right)$ and water $\left(0.6 \mathrm{~cm}^{3}\right)$. The inorganic solids were filtered, washed with EtOAc $\left(3 \times 10 \mathrm{~cm}^{3}\right)$ and extracted with boiling $\mathrm{Et}_{2} \mathrm{O}$. The combined organic layers were dried over $\mathrm{MgSO}_{4}$ and concentrated to afford (-)-29 $(0.599 \mathrm{~g}, 85 \%)$ as a colorless oil. $[\alpha]_{546}-35.0(c 1.0, \mathrm{EtOH})$; lit. ${ }^{167}[\alpha]_{\mathrm{D}}-29.8$ (c 1.0, EtOH); IR $v_{\max } / \mathrm{cm}^{-1} 3354 ;{ }^{1} \mathrm{H}$ NMR $\left(300 \mathrm{MHz}, \mathrm{CDCl}_{3}\right) \delta 4.03(\mathrm{~m}, 2 \mathrm{H}), 3.78(\mathrm{~m}, 1 \mathrm{H}), 1.68(\mathrm{q}$, $J 5.9 \mathrm{~Hz}, 2 \mathrm{H}), 1.21(\mathrm{~d}, J 5.9 \mathrm{~Hz}, 3 \mathrm{H}) ;{ }^{13} \mathrm{C} \mathrm{NMR}(75 \mathrm{MHz}$, $\left.\mathrm{CDCl}_{3}\right) \delta$ 67.4, 60.9, 40.2, 23.6.

\section{(R)-1-(tert-Butyldimethylsilyloxy)-3-butanol (8)}

To a solution of diol (-)-29 (0.453 g, $5.03 \mathrm{mmol})$ in $\mathrm{CH}_{2} \mathrm{Cl}_{2}\left(10 \mathrm{~cm}^{3}\right)$ at $0{ }^{\circ} \mathrm{C}$ was added triethylamine $\left(0.85 \mathrm{~cm}^{3}\right.$, $6.1 \mathrm{mmol})$, DMAP ( $0.065 \mathrm{~g}, 0.53 \mathrm{mmol})$ and TBSCl ( 0.800 $\mathrm{g}, 5.31 \mathrm{mmol})$. After $1 \mathrm{~h}$ the solution was diluted with $\mathrm{Et}_{2} \mathrm{O}$ $\left(20 \mathrm{~cm}^{3}\right)$ and washed with saturated $\mathrm{NH}_{4} \mathrm{Cl}$ solution $\left(15 \mathrm{~cm}^{3}\right)$. The aqueous layer was extracted with $\mathrm{Et}_{2} \mathrm{O}\left(15 \mathrm{~cm}^{3}\right)$ and organic layer was washed with brine $\left(20 \mathrm{~cm}^{3}\right)$, dried over $\mathrm{MgSO}_{4}$ and concentrated. Silica gel chromatography (EtOAc:hexane 20:80, v/v) gave monoprotected diol (+)-8 $(0.851 \mathrm{~g}, 83 \%)$ as a colorless liquid. $[\alpha]_{546}+10.0(c 1.0$, $\mathrm{CHCl}_{3}$ ); IR $v_{\text {max }} / \mathrm{cm}^{-1} 3392,1255 ;{ }^{1} \mathrm{H}$ NMR $(300 \mathrm{MHz}$, $\left.\mathrm{CDCl}_{3}\right) \delta$ 4.08-3.96 (m, 1H), 3.93-3.76 (m, 2H), $3.0(\mathrm{~s}, \mathrm{br}$, $1 \mathrm{H}), 1.74-1.56(\mathrm{~m}, 2 \mathrm{H}), 1.18(\mathrm{~d}, J 6.0 \mathrm{~Hz}, 3 \mathrm{H}), 0.89(\mathrm{~s}$, 9H), 0.07 (s, 6H); ${ }^{13} \mathrm{C} \mathrm{NMR} \mathrm{(75} \mathrm{MHz,} \mathrm{CDCl}_{3}$ ) $\delta 68.2,62.7$, 39.7, 25.6, 23.1, 17.8, -5.9, -6.0; MS (EI): $\mathrm{m} / z .75$ (100\%), $147\left(11 \%,\left[\mathrm{M}-\mathrm{C}_{4} \mathrm{H}_{9}\right]^{+}\right)$; HRMS (EI): found 147.08424; calc. for $\mathrm{C}_{6} \mathrm{H}_{15} \mathrm{O} 2 \mathrm{Si}\left[\mathrm{M}-\mathrm{C}_{4} \mathrm{H}_{9}\right]^{+} 147.08413$.

(R)-3-(tert-Butyldimethylsilyloxy)-1-methyl-propyl (3S,4S,5E)-3,4-bis-(tert-butyldimethylsilyloxy)-6-iodo-5hexenoate (30)

2,4,6-Trichlorobenzoyl chloride $\left(0.075 \mathrm{~cm}^{3}, 0.48 \mathrm{mmol}\right)$ was added to a stirred THF $\left(1.43 \mathrm{~cm}^{3}\right)$ solution of acid (-)-7 $(0.229 \mathrm{~g}, 0.46 \mathrm{mmol})$ and $\mathrm{Et}_{3} \mathrm{~N}\left(0.067 \mathrm{~cm}^{3}, 0.48 \mathrm{mmol}\right)$ at room temperature. After $18 \mathrm{~h}$, the precipitate was filtered off, and the filtrate was evaporated in vacuo to leave a solid, which was taken up in benzene $\left(1.4 \mathrm{~cm}^{3}\right)$. A solution of alcohol (+)-8 (0.098 g, $0.48 \mathrm{mmol})$ and DMAP $(0.117 \mathrm{~g}$, $0.96 \mathrm{mmol})$ in benzene $\left(4.6 \mathrm{~cm}^{3}\right)$ was added to the above solution, and stirring was continued $1.5 \mathrm{~h}$ at room temperature. The reaction mixture was diluted with $\mathrm{Et}_{2} \mathrm{O}$ $\left(25 \mathrm{~cm}^{3}\right)$ and washed with saturated aqueous $\mathrm{NaHCO}_{3}(10$ $\left.\mathrm{cm}^{3}\right)$ and brine $\left(10 \mathrm{~cm}^{3}\right)$, dried over $\mathrm{MgSO}_{4}$ and concentrated to leave an oil, which was flash chromatographed on silica gel (hexane) to give ester (-)-30 $(0.260 \mathrm{~g}, 83 \%)$ as a colorless viscous oil. $[\alpha]_{546}-60.0\left(c 1.0, \mathrm{CHCl}_{3}\right)$; IR $v_{\text {max }} / \mathrm{cm}^{-1} 1735$, 1606; ${ }^{1} \mathrm{H}$ NMR (300 MHz, $\left.\mathrm{CDCl}_{3}\right) \delta 6.67$ (dd, $J$ 14.0, 3.5 $\mathrm{Hz}, 1 \mathrm{H}), 6.27$ (dd, $J 14.0,1.5 \mathrm{~Hz}, 1 \mathrm{H}), 5.00(\mathrm{sex}, J 6.6 \mathrm{~Hz}$, $1 \mathrm{H}), 4.18-4.08$ (m, 2H), 3.64 (t, $J 6.6 \mathrm{~Hz}, 2 \mathrm{H}), 2.57$ (dd, $J$ $16.0,2.5 \mathrm{~Hz}, 1 \mathrm{H}), 2.16(\mathrm{dd}, J 16.0,8.0 \mathrm{~Hz}, 1 \mathrm{H}), 1.90-1.76$ $(\mathrm{m}, 1 \mathrm{H}), 1.76-1.60(\mathrm{~m}, 1 \mathrm{H}), 1.24(\mathrm{~d}, J 6.0 \mathrm{~Hz}, 3 \mathrm{H}), 0.89$ (s, 9H), 0.88 (s, 9H), 0.87 (s, 9H), 0.10 (s, 3H), 0.07 (s, 3H), 0.06 (s, 3H), 0.05 (s, 3H), 0.03 (s, 6H); ${ }^{13} \mathrm{C}$ NMR $(75 \mathrm{MHz}$, $\left.\mathrm{CDCl}_{3}\right) \delta 172.0,144.6,76.7,76.2,71.8,68.7,59.4,38.9$, 37.0, 25.7, 25.6, 25.5, 19.9, 18.0, 17.9, 17.6, -5.0, -5.1, -5.2, $-5.3,-5.7,-5.8$; MS (EI): $\mathrm{m} / \mathrm{z} 73$ (100\%), 629 (1\%, [M$\left.\mathrm{C}_{4} \mathrm{H}_{9}\right]^{+}$); HRMS (EI): found 629.20055; calc. for $\mathrm{C}_{24} \mathrm{H}_{50} \mathrm{O}_{5} \mathrm{Si}_{3} \mathrm{I}\left[\mathrm{M}-\mathrm{C}_{4} \mathrm{H}_{9}\right]^{+} 629.20109$.

(R)-3-(4-Methoxybenzyloxy)-1-methyl-propyl (3S,4S,5E)3,4-bis-(tert-butyldimethyl silyloxy)-6-iodo-5-hexenoate (32)

To a solution of (-)-30 $(0.114 \mathrm{~g}, 0.165 \mathrm{mmol})$ in THF $\left(2.52 \mathrm{~cm}^{3}\right)$ in a Nalgene ${ }^{\circledast}$ tube was added freshly prepared buffered pyridinium hydrofluoride (stock solution prepared from:0.208 g HF.pyridine complex, $0.47 \mathrm{~cm}^{3}$ pyridine and $1.65 \mathrm{~cm}^{3}$ of THF). After $3 \mathrm{~h}$ at room temperature the reaction was diluted with $\mathrm{Et}_{2} \mathrm{O}\left(3 \mathrm{~cm}^{3}\right)$ and neutralized by the dropwise addition of saturated $\mathrm{NaHCO}_{3}\left(6 \mathrm{~cm}^{3}\right)$. The layers were separated, the aqueous layer was extracted with $\mathrm{Et}_{2} \mathrm{O}\left(3 \times 5 \mathrm{~cm}^{3}\right)$, the combined organic layers were washed with brine $\left(5 \mathrm{~cm}^{3}\right)$ and dried over $\mathrm{MgSO}_{4}$. Evaporation under reduced pressure afforded crude alcohol which was used in the next step without further purification.

To a stirred solution of crude alcohol and pmethoxybenzyl trichloroacetimidate $(0.061 \mathrm{~g}, 0.22 \mathrm{mmol})$ in $\mathrm{Et}_{2} \mathrm{O}\left(2 \mathrm{~cm}^{3}\right)$ was added one drop of a solution of triflic acid $\left(0.05 \mathrm{~cm}^{3}\right)$ in $\mathrm{Et}_{2} \mathrm{O}\left(10 \mathrm{~cm}^{3}\right)$. After $1 \mathrm{~h}$ the reaction was quenched by the addition of saturated $\mathrm{NaHCO}_{3}\left(2 \mathrm{~cm}^{3}\right)$. The aqueous phase was extracted with $\mathrm{Et}_{2} \mathrm{O}\left(2 \times 5 \mathrm{~cm}^{3}\right)$, and the combined organic layer was washed with brine ( 5 $\mathrm{cm}^{3}$ ), dried over $\mathrm{Na}_{2} \mathrm{SO}_{4}$ and concentrated. Column chromatography (EtOAc:hexane 4:96, v/v) afforded PMBether (-)-32 (0.061 g, 53\% for 2 steps) as a colorless oil. $[\alpha]_{546}-70.0\left(c 1.0, \mathrm{CHCl}_{3}\right) ; \mathrm{IR} v_{\max } / \mathrm{cm}^{-1} 1732,1614 ;{ }^{1} \mathrm{H}$ NMR (500 MHz, $\left.\mathrm{CDCl}_{3}\right) \delta$ 7.26-7.23 (m, 2H), 6.89-6.86 (m, 2H), 6.67 (dd, $J 14.4,3.4 \mathrm{~Hz}, 1 \mathrm{H}), 6.27$ (dd, $J 14.4$, $1.7 \mathrm{~Hz}, 1 \mathrm{H}), 5.07-5.00(\mathrm{~m}, 1 \mathrm{H}), 4.40(\mathrm{ABq}, \mathrm{DAB} 16.0 \mathrm{~Hz}$, $J 11.2 \mathrm{~Hz}, 2 \mathrm{H}), 4.15-4.11(\mathrm{~m}, 2 \mathrm{H}), 3.80$ (s, 3H), 3.48 (ddt, $J 19.3,9.3,6.5 \mathrm{~Hz}, 2 \mathrm{H}), 2.55(\mathrm{dd}, J 16.0,2.3 \mathrm{~Hz}, 1 \mathrm{H}), 2.16$ (dd, $J 15.9,8.7 \mathrm{~Hz}, 1 \mathrm{H}$ ), 1.91 (ddt, $J 13.9,7.5,6.3 \mathrm{~Hz}$, 1H), 1.79 (dtd, J 14.0, 6.8, 5.3 Hz, 1H), $1.23(\mathrm{~d}, J 6.4 \mathrm{~Hz}$, $3 \mathrm{H}), 0.89$ (s, 9H), 0.87 (s, 9H), 0.10 (s, 3H), 0.07 (s, 3H), 0.06 (s, 3H), 0.05 (s, 3H); ${ }^{13} \mathrm{C}$ NMR $\left(125 \mathrm{MHz}, \mathrm{CDCl}_{3}\right.$ ) $\delta$ 171.7, 159.1, 144.3, 130.4, 129.2, 113.8, 76.7, 76.2, 72.6, 
71.8, 68.8, 66.4, 55.2, 37.1, 36.0, 25.8, 25.7, 20.1, 18.1, $17.9,-4.6,-4.7,-4.9,-5.0 ;$ MS (EI): $\mathrm{m} / z 120$ (100\%), 635 $\left(1 \%\right.$, $\left.\left[\mathrm{M}-\mathrm{C}_{4} \mathrm{H}_{9}\right]^{+}\right)$; HRMS (EI): found 635.17261; calc. for $\mathrm{C}_{26} \mathrm{H}_{44} \mathrm{O}_{6} \mathrm{Si}_{2} \mathrm{I}\left[\mathrm{M}-\mathrm{C}_{4} \mathrm{H}_{9}\right]^{+}$635.17212.

(R)-3-(4-Methoxybenzyloxy)-1-methyl-propyl 2-\{(4S,5S)5-[(E)-2-iodo-1-ethenyl]-2,2-dimethyl-1,3-dioxolan-4yl\}acetate (34)

To a solution of (-)-32 $(0.059 \mathrm{~g}, 0.085 \mathrm{mmol})$ in THF $\left(1.2 \mathrm{~cm}^{3}\right)$ in a Nalgene ${ }^{\circledR}$ tube was added freshly prepared buffered pyridinium hydrofluoride (stock solution prepared from $0.534 \mathrm{~g}$ HF.pyridine complex, $1.20 \mathrm{~cm}^{3}$ pyridine and $\left.0.81 \mathrm{~cm}^{3} \mathrm{THF}\right)$. After $20 \mathrm{~h}$ at room temperature the reaction was diluted with $\mathrm{Et}_{2} \mathrm{O}\left(10 \mathrm{~cm}^{3}\right)$ and neutralized by the dropwise addition of saturated $\mathrm{NaHCO}_{3}\left(12 \mathrm{~cm}^{3}\right)$. The layers were separated, the aqueous layer was extracted with $\mathrm{Et}_{2} \mathrm{O}\left(3 \times 5 \mathrm{~cm}^{3}\right)$, the combined organic layers were washed with brine $\left(5 \mathrm{~cm}^{3}\right)$, and dried over $\mathrm{MgSO}_{4}$. Evaporation under reduced pressure afforded crude diol which was used in the next step without further purification.

To a stirred solution of crude diol and 2,2dimethoxypropane $\left(0.523 \mathrm{~cm}^{3}, 4.25 \mathrm{mmol}\right)$ in $\operatorname{DMF}\left(1 \mathrm{~cm}^{3}\right)$ was added PPTS $(0.002 \mathrm{~g})$. After $20 \mathrm{~h}$ the reaction was quenched by addition of EtOAc $\left(6 \mathrm{~cm}^{3}\right)$ and successively washed with saturated $\mathrm{NaHCO}_{3}$ solution $\left(2 \mathrm{~cm}^{3}\right)$, brine (2 $\mathrm{cm}^{3}$ ), dried over $\mathrm{MgSO}_{4}$ and concentrated. Column chromatography (EtOAc:hexane 15:85, v/v) gave cetal (-)-34 (0.365 mg, 77\% for 2 steps $)$ as a colorless oil. $[\alpha]_{546}$ -15.0 (c 1.0, $\mathrm{CHCl}_{3}$ ); IR $v_{\max } / \mathrm{cm}^{-1} 1738,1614 ;{ }^{1} \mathrm{H}$ NMR $\left(500 \mathrm{MHz}, \mathrm{CDCl}_{3}\right) \delta$ 7.26-7.23 (m, $\left.2 \mathrm{H}\right), 6.89-6.86(\mathrm{~m}, 2 \mathrm{H})$, 6.58-6.54 (m, 2H), 5.14-5.08 (m, 1H), $4.41(\mathrm{~s}, 2 \mathrm{H}), 4.13-$ $4.05(\mathrm{~m}, 2 \mathrm{H}), 3.80(\mathrm{~s}, 3 \mathrm{H}), 3.52-3.46(\mathrm{~m}, 2 \mathrm{H}), 2.56-2.48$ (m, 2H), 1.90 (ddt, $J 14.1,8.1,6.0 \mathrm{~Hz}, 1 \mathrm{H}), 1.81$ (ddt, $J$ 14.1, 6.9, $5.1 \mathrm{~Hz}, 1 \mathrm{H}), 1.40$ (s, 6H), $1.25(\mathrm{~d}, J 6.3 \mathrm{~Hz}, 3 \mathrm{H})$; ${ }^{13} \mathrm{C}$ NMR $\left(125 \mathrm{MHz}, \mathrm{CDCl}_{3}\right) \delta 169.6,159.1,142.0,130.3$, 129.3, 113.7, 109.5, 82.7, 81.2, 76.0, 72.7, 69.4, 66.2, 55.2, 37.3, 35.9, 27.1, 26.8, 20.2; MS (EI): $\mathrm{m} / z 121$ (100\%), 489 $\left(0.2 \%,\left[\mathrm{M}-\mathrm{CH}_{3}\right]^{+}\right)$; HRMS (EI): found 489.07787; calc. for $\mathrm{C}_{20} \mathrm{H}_{26} \mathrm{O}_{6} \mathrm{I}\left[\mathrm{M}-\mathrm{CH}_{3}\right]^{+} 489.07742$.

(1R)-3-Hydroxy-1-methyl-propyl 2-\{(4S,5S)-5-[(E)-2-iodo1-ethenyl]-2,2-dimethyl-1,3-dioxolan-4-yl\}-acetate (35)

To a stirred solution of (-)-34 (0.304 g, $0.060 \mathrm{mmol})$ in $\mathrm{CH}_{2} \mathrm{Cl}_{2}\left(1 \mathrm{~cm}^{3}\right)$ containing water $\left(0.050 \mathrm{~cm}^{3}\right)$ at $0{ }^{\circ} \mathrm{C}$ was added DDQ (0.0205 g, $0.090 \mathrm{mmol})$. The reaction was allowed to warm at room temperature and after $30 \mathrm{~min}$ the reaction was filtered and washed with $\mathrm{CH}_{2} \mathrm{Cl}_{2}\left(3 \times 2 \mathrm{~cm}^{3}\right)$. The extract was washed with saturated $\mathrm{NaHCO}_{3}\left(5 \mathrm{~cm}^{3}\right)$ and brine $\left(5 \mathrm{~cm}^{3}\right)$ and dried over $\mathrm{Na}_{2} \mathrm{SO}_{4}$. The solvent was evaporated and the residue was chromatographed on a silica gel column (EtOAc:hexane 15:85, v/v) to give alcohol (-)$33(0.0204 \mathrm{~g}, 70 \%)$ as a colorless oil. $[\alpha]_{546}-18.7$ (c 1.87, $\left.\mathrm{CHCl}_{3}\right)$; IR $v_{\text {max }} / \mathrm{cm}^{-1} 3469,1738,1608 ;{ }^{1} \mathrm{H}$ NMR $(500 \mathrm{MHz}$, $\left.\mathrm{CDCl}_{3}\right) \delta$ 6.63-6.53 (m, 2H), $5.15(\mathrm{dqd}, J$ 13.0, 6.3, 4.4 $\mathrm{Hz}, 1 \mathrm{H}), 4.14-4.07$ (m, 2H), 3.70-3.60 (m, 2H), 2.62-2.52 (m, 2H), 2.23 (s, br, 1H), 1.88-1.74 (m, 2H), $1.42(\mathrm{~s}, 3 \mathrm{H})$, $1.41(\mathrm{~s}, 3 \mathrm{H}), 1.29$ (d, J $6.3 \mathrm{~Hz}, 3 \mathrm{H}) ;{ }^{13} \mathrm{C}$ NMR $(125 \mathrm{MHz}$, $\left.\mathrm{CDCl}_{3}\right) \delta 170.4,141.8,109.7,82.7,81.4,76.2,69.4,58.9$, 38.9, 37.4, 27.0, 26.8, 20.4; MS (EI): $\mathrm{m} / \mathrm{z} 97$ (100\%), 369 $\left(35 \%,\left[\mathrm{M}-\mathrm{CH}_{3}\right]^{+}\right)$; HRMS (EI): found 369.02082; calc. for $\mathrm{C}_{12} \mathrm{H}_{18} \mathrm{O}_{5} \mathrm{I}\left[\mathrm{M}-\mathrm{CH}_{3}\right]^{+} 369.01990$.

(4S, 5S, 8S, 10R)-8-Hydroxy-4,5-bis-(tert-butyldimethylsilyloxy)-10-methyl-3,4,5,8,9,10-hexahydro- $2 \mathrm{H}-2$ oxecinone (38a)

To a solution of (-)-30 (0.0503 g, $0.073 \mathrm{mmol})$ in THF $\left(1.13 \mathrm{~cm}^{3}\right)$ in a Nalgene ${ }^{\circledR}$ tube was added freshly prepared buffered pyridinium hydrofluoride (stock solution prepared from:0.092 $\mathrm{g}$ HF.pyridine complex, $0.20 \mathrm{~cm}^{3}$ pyridine and $0.73 \mathrm{~cm}^{3} \mathrm{THF}$ ). After $3 \mathrm{~h}$ at room temperature the reaction was diluted with $\mathrm{Et}_{2} \mathrm{O}\left(4 \mathrm{~cm}^{3}\right)$ and neutralized by the dropwise addition of saturated $\mathrm{NaHCO}_{3}$. The layers were separated, the aqueous layer was extracted with $\mathrm{Et}_{2} \mathrm{O}(4 \mathrm{x}$ $3 \mathrm{~cm}^{3}$ ), the combined organic layers were washed with brine $\left(5 \mathrm{~cm}^{3}\right)$, and dried over $\mathrm{MgSO}_{4}$. Evaporation under reduced pressure afforded crude alcohol $\mathbf{3 1}$ which was used in the next step without further purification.

To a suspension of Dess Martin periodinane $(0.176 \mathrm{~g}$, $0.42 \mathrm{mmol})$ in $\mathrm{CH}_{2} \mathrm{Cl}_{2}\left(1.83 \mathrm{~cm}^{3}\right)$ containing water $(0.008$ $\mathrm{cm}^{3}$ ) was added a solution of the alcohol above in $\mathrm{CH}_{2} \mathrm{Cl}_{2}$ $\left(0.50 \mathrm{~cm}^{3}\right)$. The reaction mixture was stirred $1 \mathrm{~h}$, and it was diluted with EtOAc $\left(12 \mathrm{~cm}^{3}\right)$. After the addition of saturated $\mathrm{NaHCO}_{3}\left(12 \mathrm{~cm}^{3}\right)$, the organic layer was separated and aqueous layer was extracted with EtOAc $\left(2 \times 5 \mathrm{~cm}^{3}\right)$. The combined organic layer was washed with aqueous $1 \mathrm{mo} \mathrm{L}^{-1} \mathrm{NaHSO}_{3}\left(10 \mathrm{~cm}^{3}\right)$, brine $\left(10 \mathrm{~cm}^{3}\right)$ and dried over $\mathrm{MgSO}_{4}$. Concentration produced the crude aldehyde 6 that was used in next step without further purification.

To a suspension of $\mathrm{CrCl}_{2}(0.130 \mathrm{~g}, 1.06 \mathrm{mmol})$ containing $0.5 \% \mathrm{~mol}$ of $\mathrm{NiCl}_{2}$ in degassed DMF $\left(12 \mathrm{~cm}^{3}\right)$ was added via cannula and under ice bath cooling a solution of aldehyde 6 (previously dried with $2 \times 0.5 \mathrm{~cm}^{3}$ benzene in vacuo) in degassed DMF $\left(2.6 \mathrm{~cm}^{3}\right)$. The reaction mixture was stirred overnight at room temperature, and the solvent was destilled off under vacuum $(0.1 \mathrm{mmHg})$. The residue was dissolved in saturated $\mathrm{NH}_{4} \mathrm{Cl}\left(10 \mathrm{~cm}^{3}\right)$ and extracted with $\mathrm{Et}_{2} \mathrm{O}\left(4 \times 10 \mathrm{~cm}^{3}\right)$ and $\mathrm{EtOAc}\left(2 \times 10 \mathrm{~cm}^{3}\right)$. The organic layer was washed with brine $\left(40 \mathrm{~cm}^{3}\right)$ and dried over $\mathrm{MgSO}_{4}$. The crude product was purified by flash 
chromatography (EtOAc:hexane 10:90, v/v) to yield $(-)-38 \mathbf{a}(0.010 \mathrm{~g}, 31 \%$ for 3 steps $)$ as a colorless oil. $[\alpha]_{546}$ -35.0 (c 1.0, $\mathrm{CHCl}_{3}$ ); IR $v_{\max } / \mathrm{cm}^{-1} 3435,1738 ;{ }^{1} \mathrm{H}$ NMR $\left(300 \mathrm{MHz}, \mathrm{CDCl}_{3}\right) \delta 5.92-5.72(\mathrm{~m}, 2 \mathrm{H}), 5.08$ (dqd, $J$ 11.0, $6.2,2.2 \mathrm{~Hz}, 1 \mathrm{H}$ ), 4.26-4.14 (m, 2H), 3.91 (ddd, $J$ 6.2, 4.4, $1.8 \mathrm{~Hz}, 1 \mathrm{H}), 2.57$ (dd, J 3.2, $1.8 \mathrm{~Hz}, 1 \mathrm{H}), 2.17$ (dd, $J 13.2$, $6.2 \mathrm{~Hz}, 1 \mathrm{H}), 1.86(\mathrm{ddd}, J 13.9,4.0,2.3 \mathrm{~Hz}, 1 \mathrm{H}), 1.76(\mathrm{dt}, J$ $13.9,10.6 \mathrm{~Hz}, 1 \mathrm{H}), 1.63$ (s, br, 1H), $1.20(\mathrm{~d}, J 6.6 \mathrm{~Hz}, 3 \mathrm{H})$, 0.95 (s, 9H), 0.94 (s, 9H), 0.13 (s, 3H), 0.09 (s, 3H), 0.07 (s, 3H), 0.06 (s, 3H); ${ }^{13} \mathrm{C} \mathrm{NMR}\left(75 \mathrm{MHz}, \mathrm{CDCl}_{3}\right) \delta 170.6$, 134.8, 129.2, 74.4, 73.4, 72.8, 67.1, 42.7, 35.2, 25.7, 25.5, 21.2, 18.0, 17.8, -5.1, -5.2, -5.3 (x2); MS (EI): $\mathrm{m} / z .73$ $(100 \%), 387\left(3 \%,\left[\mathrm{M}-\mathrm{C}_{4} \mathrm{H}_{9}\right]^{+}\right)$; HRMS (EI): found 387.20234; calc. for $\mathrm{C}_{18} \mathrm{H}_{35} \mathrm{O}_{5} \mathrm{Si}_{2}\left[\mathrm{M}-\mathrm{C}_{4} \mathrm{H}_{9}\right]^{+}$387.20231;

(3aS, 7R, 9RS, 11aS)-9-Hydroxy-2,2,7-trimethyl-4,5, 7,8,9,11a-hexahydro-3aH-[1,3]-dioxolo[4,5-d]oxecin-5one $(39 a / 39 b)$

To a suspension of Dess Martin periodinane $(0.0286 \mathrm{~g}$, $0.068 \mathrm{~mol})$ in $\mathrm{CH}_{2} \mathrm{Cl}_{2}\left(1.0 \mathrm{~cm}^{3}\right)$ containing water $(0.002$ $\left.\mathrm{cm}^{3}\right)$ was added a solution of alcohol (-)-35 in $\mathrm{CH}_{2} \mathrm{Cl}_{2}(0.27$ $\left.\mathrm{cm}^{3}\right)$. The reaction mixture was stirred $1 \mathrm{~h}$, and it was diluted with AcOEt $\left(7 \mathrm{~cm}^{3}\right)$. After the addition of saturated $\mathrm{NaHCO}_{3}\left(7 \mathrm{~cm}^{3}\right)$, the organic layer was separated and aqueous layer was extracted with EtOAc $\left(2 \times 5 \mathrm{~cm}^{3}\right)$. The combined organic layer was washed with aqueous $1 \mathrm{~mol}$ $\mathrm{L}^{-1} \mathrm{NaHSO}_{3}\left(5 \mathrm{~cm}^{3}\right)$, brine $\left(5 \mathrm{~cm}^{3}\right)$ and dried over $\mathrm{MgSO}_{4}$. Concentration produced the crude aldehyde $\mathbf{3 7}$ that was used in next step without further purification.

To a suspension of $\mathrm{CrCl}_{2}(0.077 \mathrm{~g}, 0.63 \mathrm{mmol})$ containing $0.5 \% \mathrm{~mol}$ of $\mathrm{NiCl}_{2}$ in degassed DMF $\left(7 \mathrm{~cm}^{3}\right)$ was added via cannula and under ice bath cooling a solution of the aldehyde 37 (azeotroped $2 \times 0.5 \mathrm{~cm}^{3}$ benzene in vacuo) in degassed DMF $\left(1.6 \mathrm{~cm}^{3}\right)$. The reaction mixture was stirred overnight at room temperature, and the solvent was destilled off under vacuum $(0.1 \mathrm{mmHg})$. The residue was dissolved in saturated $\mathrm{NH}_{4} \mathrm{Cl}\left(15 \mathrm{~cm}^{3}\right)$ and extracted with $\mathrm{Et}_{2} \mathrm{O}\left(4 \times 10 \mathrm{~cm}^{3}\right)$ and EtOAc $\left(2 \times 10 \mathrm{~cm}^{3}\right)$. The organic layer was washed with brine $\left(20 \mathrm{~cm}^{3}\right)$ and dried over $\mathrm{MgSO}_{4}$. The crude product was purified by flash chromatography (EtOAc:hexane 20:80, v/v) to yield $\mathbf{3 9 a} / \mathbf{3 9 b}$ ( $0.006 \mathrm{~g}, 54 \%$ for 2 steps) as a 2:1 unseparable mixture of diastereoisomers. Major [39b]: ${ }^{1} \mathrm{H} \mathrm{NMR}\left(500 \mathrm{MHz}, \mathrm{CDCl}_{3}\right)$ $\delta 5.69$ (dd, $J 16.4,7.3 \mathrm{~Hz}, 1 \mathrm{H}), 5.57$ (ddd, $J 16.6,8.5,1.1$ $\mathrm{Hz}, 1 \mathrm{H}), 5.26$ (qd, J 6.8, $2.2 \mathrm{~Hz}, 1 \mathrm{H}), 4.62-4.49(\mathrm{~m}, 1 \mathrm{H})$, 4.12 (t, $J 8.6 \mathrm{~Hz}, 1 \mathrm{H}), 3.93$ (ddd, $J 10.9,8.6,5.2 \mathrm{~Hz}, 1 \mathrm{H}$ ), $3.06(\mathrm{dd}, J 15.2,5.2 \mathrm{~Hz}, 1 \mathrm{H}), 2.43(\mathrm{dd}, J 15.3,11.1 \mathrm{~Hz}$, 1H), 2.08 (ddd, $J 14.9,5.6,2.2 \mathrm{~Hz}, 1 \mathrm{H}), 1.44$ (s, 3H), 1.42 (s, 3H), 1.29 (d, J 6.9 Hz, 3H). Minor [39a]: ' $\mathrm{H}$ NMR (500 $\left.\mathrm{MHz}, \mathrm{CDCl}_{3}\right) \delta 6.00-5.90(\mathrm{~m}, 2 \mathrm{H}), 5.05$ (dqd, $J$ 9.5, 6.7,
$1.3 \mathrm{~Hz}, 1 \mathrm{H}), 4.39-4.34(\mathrm{~m}, 1 \mathrm{H}), 4.24-4.20(\mathrm{~m}, 1 \mathrm{H}), 3.96$ (ddd, $J 10.8,8.7,5.5 \mathrm{~Hz}, 1 \mathrm{H}), 3.09$ (dd, $J 14.8,5.5 \mathrm{~Hz}$, 1H), 2.44 (dd, $J 14.8,10.8 \mathrm{~Hz}, 1 \mathrm{H}$ ), 2.15 (ddd, $J 14.2,4.6$, $1.2 \mathrm{~Hz}, 1 \mathrm{H}), 1.71$ (dd, $J 4.2,9.4 \mathrm{~Hz}, 1 \mathrm{H}), 1.46(\mathrm{~s}, 3 \mathrm{H})$, 1.42 (s, 3H), 1.27 (d, J $6.9 \mathrm{~Hz}, 3 \mathrm{H})$.

\section{Decarestrictine D [(-)-1]}

To a solution of (-)-38a $(0.0062 \mathrm{~g}, 0.014 \mathrm{mmol})$ and TBAF $(0.011 \mathrm{~g}, 0.042 \mathrm{mmol})$ in $\mathrm{CH}_{3} \mathrm{CN}\left(0.85 \mathrm{~cm}^{3}\right)$ was added $\mathrm{HF} 40 \%\left(0.14 \mathrm{~cm}^{3}\right)$. The solution was stirred at room temperature $2.5 \mathrm{~h}$ and diluted with EtOAc $\left(3 \mathrm{~cm}^{3}\right)$. Neutralization with saturated $\mathrm{NaHCO}_{3}$ solution allowed phase separation, and the aqueous layer was extracted with EtOAc $\left(3 \times 2 \mathrm{~cm}^{3}\right)$. The combined organic layers were washed with brine $\left(5 \mathrm{~cm}^{3}\right)$, and dried over $\mathrm{MgSO}_{4}$. Silicagel chromatoghaphy (EtOAc) afforded the (-)decarestrictine $\mathrm{D}(-)-\mathbf{1}(0.0025 \mathrm{~g}, 83 \%)$ as a white solid. $[\alpha]_{\mathrm{D}}-70.9\left(c 0.24, \mathrm{CHCl}_{3}\right) ;[\alpha]_{546}-83.3\left(c 0.24, \mathrm{CHCl}_{3}\right)$; lit. ${ }^{1 \mathrm{a}}[\alpha]_{\mathrm{D}}-67.0\left(c \quad 0.26, \mathrm{CHCl}_{3}\right) ;{ }^{1} \mathrm{H}$ NMR $(500 \mathrm{MHz}$, $\left.\mathrm{CD}_{3} \mathrm{OD}\right) \delta 5.83(\mathrm{ddd}, J 15.9,9.3,1.5 \mathrm{~Hz}, 1 \mathrm{H}), 5.74(\mathrm{dd}, J$ $15.9,3.1 \mathrm{~Hz}, 1 \mathrm{H}), 5.17(\mathrm{dqd}, J 11.3,6.5,1.6 \mathrm{~Hz}, 1 \mathrm{H}), 4.19$ (ddd, $J$ 4.5, 3.2, $1.5 \mathrm{~Hz}, 1 \mathrm{H}$ ), 4.07 (ddd, $J$ 10.7, 9.3, 3.4 $\mathrm{Hz}, 1 \mathrm{H}$ ), 3.94 (ddd, $J$ 6.8, 4.6, $2.4 \mathrm{~Hz}, 1 \mathrm{H}$ ), 2.59 (dd, $J$ 14.0, $2.3 \mathrm{~Hz}, 1 \mathrm{H}), 2.31$ (dd, $J 14.1,6.9 \mathrm{~Hz}, 1 \mathrm{H}), 1.85$ (ddd, $J 13.9,3.6,1.5 \mathrm{~Hz}, 1 \mathrm{H}), 1.72(\mathrm{dt}, J 13.9,11.2 \mathrm{~Hz}, 1 \mathrm{H}), 1.21$ $(\mathrm{d}, J 6.7 \mathrm{~Hz}, 3 \mathrm{H}) ;{ }^{13} \mathrm{C}$ NMR $\left(75 \mathrm{MHz}, \mathrm{CD}_{3} \mathrm{OD}\right) \delta 175.3$, 133.9, 130.1, 73.9, 72.5, 72.2, 68.2, 42.9, 33.0, 21.0.

\section{Acknowledgments}

The authors wish to acknowledge Fapesp (Brazil), Finep (Brazil) and Volkswagen Stiftung (Germany) for financial support. RAP and MMV thank CNPq (Brazil) for fellowships.

\section{References}

1. (a) Grabley, S.; Granzer, E.; Hütter, K.; Ludwig, D.; Mayer, M.; Thiericke, R.; Till, G.; Wink, J.; Phillips, S.; Zeeck, A. J. Antibiotics 1992, 45, 56; (b) Göhrt, A.; Zeeck, A.; Hütter, K.; Kirsch, R.; Kluge, H.; Thiericke, R. J. Antibiotics 1992, 45, 66; (c) Grabley, S.; Hamann, P.; Hütter, K.; Kirsch, R.; Kluge, H.; Mayer, M.; Thiericke, R.; Zeeck, A. J. Antibiotics 1992, 45, 1176; (d) Ayer, W. A.; Sun, M.; Browne, L. M.; Brinen, L. S.; Clardy, J. J. Nat. Prod. 1992, 55, 649.

2. Dräger, D.; Garming, A.; Maul, C.; Noltemeyer, M.; Thiericke, R.; Zerlin, M.; Kirschning, A. Chem. Eur. J. 1998, 4, 1324. 
3. Andrus, M. B.; Shih, T.-L. J. Org. Chem. 1996, 61, 8780 .

4. For recent reviews see: (a) Dräger, G.; Kirschning, A.; Thiericke, R.; Zerlin, M. Nat. Prod. Rep. 1996, 13, 365; (b) Collins, I. J. Chem. Soc., Perkin Trans. 1 1999, 1377.

5. Moore, B. P.; Brown, W. V. Aust. J. Chem. 1976, 29 , 1365.

6. Nukina, M.; Sassa, T.; Ikeda, M. Tetrahedron Lett. 1980, 21, 301.

7. Rousseau, G. Tetrahedron 1995, 21, 2777.

8. Pilli, R. A.; Victor, M. M. Tetrahedron Lett. 1998, 39, 4421 .

9. For recent reviews see: (a) Wessjohann, L. A.; Scheid, G. Synthesis 1999, 1; (b) Avalos, M.; Babiano, R.; Cintas, P.; Jiménez, J. L.; Palacios, J. C. Chem. Soc. Rev. 1999, 28, 169; (c) Fürstner, A. Chem. Rev. 1999, 99, 991.

10. (a) Pilli, R. A., de Andrade, C. K. Z.; Souto, C. R. O.; de Meijere, A. J. Org. Chem. 1998, 63, 7811; (b) Oddon, G.; Uguen, D. Tetrahedron Lett. 1998, 39, 1157.

11. Seebach, D.; Brunner, A.; Bachmann, B. M.; Hoffmann, T.; Kühnle, F. N. M.; Lengweiler, U. D. in Biopolymers and-oligomers of (R)-3-Hydroxyalkanoic Acids, vol. 28, Ernst Schering Research Foundation, Berlin, 1995.

12. (a) Sharpless, H. D.; Amberg, W.; Bennani, Y. L.; Crispino, G. A.; Hartung, J.; Jeong, K.-S.; Kwong, H.-L.; Morikawa, K.; Wang, Z.-M.; Xu, D.; Zang, X.L. J. Org. Chem. 1992, 57, 2768; (b) Review: Kolb, H. C.; van Nieuwenhze, M. S.; Sharpless, K. B. Chem. Rev. 1994, 94, 2483.

13. Kress, M. H.; Ruel, R.; Miller, W. H.; Kishi, Y. Tetrahedron Lett. 1993, 34, 6003.

14. Schreiber, S. L.; Meyers, H. V. J. Am. Chem. Soc. 1988 , 110, 5198.

15. McDougal, P. G.; Rico, J. G.; Oh, Y. I.; Condon, B. D. J. Org. Chem. 1986, 51, 3388.

16. Column: heptakis-(2,6-methyl-3-pentyl)- $\alpha$-cyclodextrine, $25 \mathrm{~m}$, id $0.25 \mathrm{~mm}, 20 \%$ in OV 1701, FID.

17. Takai, K.; Nitta, K; Utimoto, K. J. Am. Chem. Soc. 1986, 108, 7408.

18. Major isomer $(E): \delta 6.48(\mathrm{dd}, J 14.5,0.8 \mathrm{~Hz}, \mathrm{H} 5)$, $6.59(\mathrm{dd}, J 14.5,5.8 \mathrm{~Hz}, \mathrm{H} 4)$; minor isomer: $\delta 6.29(\mathrm{t}$, $J 8.0 \mathrm{~Hz}, \mathrm{H} 4), 6.53$ ( $J$ 8.0, $0.8 \mathrm{~Hz}, \mathrm{H} 5)$.

19. Evans, D. A.; Black, W. C. J. Am. Chem. Soc. 1993 , $115,4497$.
20. Attempts to reduce the ester with $\mathrm{LiAlH}_{4}$ followed by oxidation of the aldehyde did not provide better yields.

21. 24E: $\delta 6.22$ (dd, $J$ 14.5, $1.8 \mathrm{~Hz}, \mathrm{H6})$ and 6.69 (dd, $J$ $14.5,4.0 \mathrm{~Hz}, \mathrm{H} 5)$.

22. Hodgson, D. M.; Boulton, L. T.; Maw, G. N. Tetrahedron Lett. 1994, 35, 2234.

23. For additional examples of olefination of sterically hindered aldehydes, see: (a) ref. 10a.; (b) Baker, R.; Castro, J. L. J. Chem. Soc., Perkin Trans. 1 1989, 190; (c) Chackalamannil, S.; Davies, R. J.; Asberon, T.; Doller, D.; Leone, D. J. Am. Chem. Soc. 1996, 118, 9812; (d) Williams, D. R.; Kissel, W. S. J. Am. Chem. Soc. 1998, 120, 11198; (e) Fujiwara, K.; Murai, A. J. Am. Chem. Soc. 1998, 120, 10770.

24. For additional examples, see: (a) Oikawa, M.; Ueno, T.; Oikawa, H.; Ichihara, A. J. Org. Chem. 1995, 60, 5048; (b) Keck, G. E.; Palani, A.; McHardy, S. F. J. Org. Chem. 1994, 59, 3113.

25. (a) ref. 10a; (b) Oikawa, Y.; Tanaka, T.; Hamada, T.; Yonemitsu, O. Chem. Pharm. Bull. 1987, 35, 2196.

26. Evans, P. A.; Roseman, J. D.; Garber, L. T. Synth. Commun. 1996, 26, 4685.

27. Seebach, D,; Züger, M. Helv. Chim. Acta 1982, 65, 495.

28. Still, W. C.; Galynker, I. Tetrahedron 1981, 37, 3981.

29. MacMillan, D. W. C.; Overman, L. E. J. Am. Chem. Soc. 1995, 117, 10391.

30. Inanaga, J.; Hirata, K.; Saeki, H.; Katsuki, T.; Yamaguchi, M. Bull. Chem. Soc. Jpn. 1979, 52, 1989.

31. Secondary to primary acyl migration was observed for alcohol $\mathbf{3 1}$.

32. During chromatographic purification and/or storing formation of the corresponding butyrolactone was observed from diol $\mathbf{3 3}$.

33. Horita, K.; Yoshioka, T.; Tanaka, T.; Oikawa, Y.; Yonemitsu, O. Tetrahedron 1986, 42, 3021.

34. a) Dess, D. B., Martin, J. C., J. Org. Chem. 1983, 48, 4155; b) Dess, D. B., Martin, J. C., J. Am. Chem. Soc. 1991, 113, 7277; c) Meyer, S. D., Schreiber, S. L. J. Org. Chem. 1994, 59, 7549.

35. Wessjohan, L., Gabriel, T., J. Org. Chem. 1997, 62, 3772 .

36. Marshall, J. A., Beadoin, S. J. Org. Chem. 1994, 59, 6614.

Received: November 14, 2000

Published on the web: May 16, 2001

FAPESP helped in meeting the publication costs of this article. 